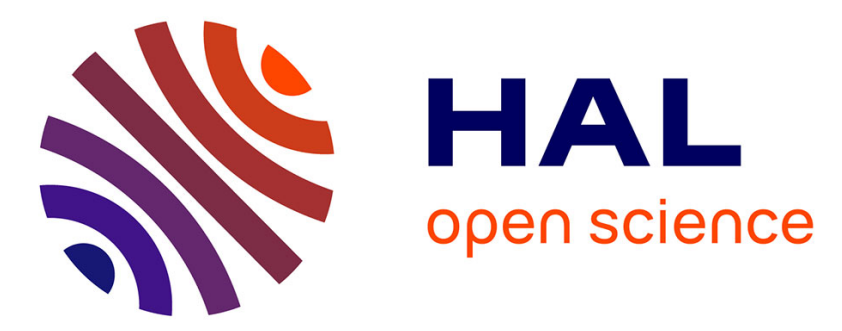

\title{
The kinematics of the Dasht-e Bayaz earthquake fault during Pliocene-Quaternary: implications for the geodynamics of eastern Central Iran
}

\author{
Fariborz Baniadam, Esmaeil Shabanian, Olivier Bellier
}

\section{- To cite this version:}

Fariborz Baniadam, Esmaeil Shabanian, Olivier Bellier. The kinematics of the Dasht-e Bayaz earthquake fault during Pliocene-Quaternary: implications for the geodynamics of eastern Central Iran. Tectonophysics, 2019, 10.1016/j.tecto.2019.228218 . hal-02464593

\section{HAL Id: hal-02464593 https://hal.science/hal-02464593}

Submitted on 3 Feb 2020

HAL is a multi-disciplinary open access archive for the deposit and dissemination of scientific research documents, whether they are published or not. The documents may come from teaching and research institutions in France or abroad, or from public or private research centers.
L'archive ouverte pluridisciplinaire HAL, est destinée au dépôt et à la diffusion de documents scientifiques de niveau recherche, publiés ou non, émanant des établissements d'enseignement et de recherche français ou étrangers, des laboratoires publics ou privés. 
Tectonophysics

Elsevier Editorial system(tm) for

Manuscript Draft

Manuscript Number: TECTO13372R2

Title: The kinematics of the Dasht-e Bayaz earthquake fault during Pliocene-Quaternary: implications for the geodynamics of eastern Central Iran

Article Type: Research Paper

Keywords: fault kinematic analysis; paleostress; active tectonics; Dashte Bayaz Fault; Lut Block; Central Iran

Corresponding Author: Dr. Esmaeil Shabanian,

Corresponding Author's Institution: IASBS

First Author: Fariborz Baniadam, Ph.D. student

Order of Authors: Fariborz Baniadam, Ph.D. student; Esmaeil Shabanian; olivier Bellier

Abstract: The Arabia - Eurasia convergence is accommodated across the Iranian plateau and surrounding mountain ranges. Strike-slip faults play significant roles in the current deformation of the Iranian plateau and were responsible for several moderate to large earthquakes, especially in east of Iran. The sinistral Dasht-e Bayaz fault shows conspicuous seismic and geological activities, while the role of the fault in the accommodation of active convergence is still debated. This paper focuses on the Pliocene-Quaternary to present-day states of stress in the region affected by the Dasht-e Bayaz fault. We applied the fault-slip inversion technique to both kinds of seismologic and geological fault slip data. The inversion results indicate a mean $\mathrm{N} 045 \pm 5^{\circ} \mathrm{E}$ trending $\sigma 1$ in the modern stress field, which agrees with the present-day tectonic regime (regional $\mathrm{N} 050 \pm 05^{\circ} \mathrm{E}$ trending $\left.\sigma 1\right)$ deduced from the inversion of earthquake focal mechanism data. The paleostress state is characterized by a $\mathrm{N} 135 \pm 15^{\circ} \mathrm{E}$ trending regional mean $\sigma 1$, with a transpressional stress regime; $\mathrm{E}-\mathrm{W}$ faults of the region such as the Dasht-e Bayaz fault were reverse dextral in this paleostress field. We show that the shift in fault kinematics during the Pliocene-Quaternary times has not been restricted to northeastern parts of the Iranian plateau. The cross-cutting relationship between active $\mathrm{N}-\mathrm{S}$ dextral and $\mathrm{E}-\mathrm{W}$ sinistral faults indicates a crosswise to conjugate fault arrangement in the middle and the eastern end of the Dasht-e Bayaz fault. Integrating our results at a larger regional scale, we present a kinematic model in which the region between Lut and Kopeh Dagh is divided by the Doruneh fault into two tectonic domains. In the northern domain, active convergence is taken up by the extrusion of fault-bounded crustal blocks while, in the southern domain the convergence is accommodated through crosswise strike-slip faulting accompanied by reverse/thrust faulting in confining wedges.

Research Data Related to this Submission 


\section{The kinematics of the Dasht-e Bayaz earthquake fault during Pliocene-Quaternary: implications for the geodynamics of eastern Central Iran}

Fariborz Baniadam ${ }^{\mathrm{a}}{ }^{\mathrm{b}}$ Esmaeil Shabanian $^{\mathrm{c}}$, Olivier Bellier $^{\mathrm{a}}$

\footnotetext{
${ }^{a}$ Aix Marseille Univ, CNRS, IRD, INRA, Coll France, CEREGE, Aix-en-Provence, France, bellier@ cerege.fr

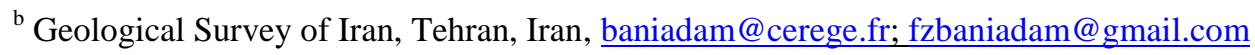

${ }^{\mathrm{c}}$ Department of Earth Sciences, Institute for Advanced Studies in Basic Sciences (IASBS), Zanjan 45137-66731, Iran, corresponding author: E-mail address: es.shabanian@gmail.com; shabanian@iasbs.ac.ir
}

8

(1)

Keywords: Fault kinematic analysis; Paleostress; Active tectonics; Dasht-e Bayaz Fault; Lut Block; Central Iran

\footnotetext{
Abstract

The Arabia - Eurasia convergence is accommodated across the Iranian plateau and surrounding mountain ranges. Strike-slip faults play significant roles in the current deformation of the Iranian plateau and were responsible for several moderate to large earthquakes, especially in east of Iran. The sinistral Dasht-e Bayaz fault shows conspicuous seismic and geological activities, while the role of the fault in the accommodation of active convergence is still debated. This paper focuses on the Pliocene-Quaternary to present-day states of stress in the region affected by the Dasht-e Bayaz fault. We applied the fault-slip inversion technique to both kinds of seismologic and geological fault slip data. The inversion results indicate a mean $\mathrm{N} 045 \pm 5^{\circ} \mathrm{E}$ trending $\sigma_{1}$ in the modern stress field, which agrees with the present-day tectonic regime (regional $\mathrm{N} 050 \pm 05^{\circ} \mathrm{E}$ trending $\sigma_{1}$ ) deduced from the inversion of earthquake focal mechanism data. The paleostress state is characterized by a $\mathrm{N} 135 \pm 15^{\circ} \mathrm{E}$ trending regional mean $\sigma_{1}$, with a transpressional stress regime; E-W faults of the region such as the Dasht-e Bayaz fault were reverse dextral in this paleostress field. We show that the shift in fault kinematics during the Pliocene-Quaternary times has not been restricted to northeastern parts of the Iranian plateau. The cross-cutting relationship
} 
between active N-S dextral and E-W sinistral faults indicates a crosswise to conjugate fault arrangement in the middle and the eastern end of the Dasht-e Bayaz fault. Integrating our results at a larger regional scale, we present a kinematic model in which the region between Lut and Kopeh Dagh is divided by the Doruneh fault into two tectonic domains. In the northern domain, active convergence is taken up by the extrusion of fault-bounded crustal blocks while, in the southern domain the convergence is accommodated through crosswise strike-slip faulting accompanied by reverse/thrust faulting in confining 32 wedges.

\section{Introduction}

The convergence between Arabia and Eurasia is responsible for current deformation in Iran. Nearly all convergence is accommodated across the Iranian plateau and surrounding mountain ranges such as Zagros, Alborz and Kopeh Dagh; the collision boundaries correspond approximately to the political borders of Iran. The Makran tectonic province is the surface expression of the active subduction of Arabia beneath the Iranian micro-continent (e.g., Walpersdorf et al., 2014; Burg, 2018). the pieces of the puzzle of this convergence are progressively fitting together. Numerous studies have attempted to describe the role of strike-slip faults in the active tectonics of the collision zone (e.g., Hessami et al., 2003; Karakhanian et al., 2004; Talebian and Jackson, 2004; Walker and Jackson, 2004;

44 Regard et al., 2005, 2006; Authemayou et al., 2006; Meyer and Le Dortz, 2007; Shabanian et al., 2009a, 2009b and 2012a; Molnar and Dayem, 2010; Farbod et al., 2011, 2016; Calzolari et al., 2015, 2016, 2018). According to these studies, strike-slip faults play significant roles in the current deformation of the

47 Iranian plateau and were responsible for several moderate to large earthquakes especially in east of Iran 48 (e.g., Dasht-e Bayaz 31 August 1968, Koli-Buniabad 27 November 1979 and Zirkuh-Qayen 10 May 49 1997). Since Pliocene (5.3-2.6 Ma), the dominant tectonic regime in the Iranian plateau and surrounding 50 deformation belts has changed from compressional to strike-slip (Regard et al., 2005, 2006; Authemayou 
et al., 2006; Shabanian et al., 2009a, 2009b, 2010; Farbod et al., 2011, 2016; Ghods et al., 2015; Tadayon et al., 2017, 2018; Taghipour et al., 2018). Even in thrust-fold domains such as the Zagros and Alborz belts, where the main way of accommodation of Arabia-Eurasia convergence is crustal shortening, the role of strike-slip faulting is determinant (e.g., Talebian and Jackson, 2004; Authemayou et al., 2006, 2009). and Philip, 1997; Karakhanian et al., 2004; Ghods et al., 2015), the Main Recent Fault in Zagros (Tchalenko et al., 1974; Braud and Ricou, 1975; Ricou et al., 1977; Berberian, 1995; Talebian and Jackson, 2004), the Minab-Zendan-Palami fault zone at the Zagros - Makran transition (Regard et al., 60 2005) and the Bakharden-Quchan fault system in Kopeh Dagh (Shabanian et al., 2009a, 2009b) as well as 61 the faults that re-activate the Sistan Suture zone in the east of Iran (e.g., Vernant et al., 2004; Walker and Jackson, 2004) in accommodation of the Arabia-Eurasia convergence is nearly well-known. These strikeslip faults act as block boundaries along which the blocks are moved in accordance with the overall deformation in the Arabia - Eurasia collision zone (e.g., Walpersdorf et al., 2006, 2014; Tavakoli et al., 2008; Shabanian et al., 2009b; Mousavi et al., 2013; Ghods et al., 2015).

Recent geodetic (e.g., Vernant et al., 2004; Reilinger et al., 2006; Mousavi et al., 2013; Walpersdorf et al., 2014) and geological studies (Shabanian et al., 2009a, 2009b, 2010, 2012b; Farbod et al., 2011, 2016) in NE Iran have revealed that active deformation is localized along block-bounding crustal faults. In Central Iran, GPS-derived velocity fields (Walpersdorf et al., 2014) and GPS block modeling (Reilinger et al., 2006; Walpersdorf et al., 2014) show that about 90 percent of the $5.7 \mathrm{~mm} / \mathrm{yr}$ northward motion of the Lut block - Eurasia is transferred to the north of the E-W Doruneh fault (Fig. 1). To the north, the Bakharden-Quchan fault system takes up $4.1-4.6 \mathrm{~mm} / \mathrm{yr}$ of this dextral faulting across the Kopeh Dagh Mountains (Shabanian et al., 2009a, 2009b, 2012b; Mousavi et al., 2013). In other words, this fault system accommodates $80 \%$ of Central Iran-Eurasia convergence $(\sim 5.1 \mathrm{~mm} / \mathrm{yr})$ north of $37^{\circ} \mathrm{N}$. In this tectonic context, there are other strike-slip faults such as the Doruneh and Dasht-e Bayaz 76 faults which affect the Iranian plateau and are characterized by conspicuous seismic and/or geological 
activities. Nevertheless, the role of these faults in the accommodation of the active convergence has been a matter of debate (e.g., Farbod et al., 2011, 2016; Nozaem et al., 2013; Calzolari et al., 2015, 2016, 2018; Tadayon et al., 2017 and 2018). Interestingly, these E-W faults are perpendicular to the N-S active block motions in the Lut and separate the N-S dextral strike-slip faults of the Lut borders (the Nayband and Sistan suture zone) to the south from the NW-trending structures of the Binalud and Kopeh Dagh deformation domains to the north (Fig. 1).

Our understanding of the processes involved in the plate convergence improves progressively, but we still need to know more about (1) both the pattern and kinematics of deformation in each part of the convergence/collision zone and (2) the role of intracontinental crustal faults in the accommodation of this deformation within the plateau. During the last century, areas such as Dasht-e Bayaz, Tabas, and Bam that were considered as stable areas in the interior of rigid blocks have been affected by large destructive earthquakes occurring on mostly unknown faults (e.g., Walker et al., 2011; Berberian, 2014). After the destructive $1968 \mathrm{Mw} 7.1$ earthquake, for instance, the Dasht-e Bayaz area has been one of the most seismically active domains in Iran. Right after the Dasht-e Bayaz main shock in 1968, this area has been studied from different points of view. The first studies focused on mapping of the coseismic rupture and post-earthquake observations (e.g. Ambraseys and Tchalenko, 1969; Tchalenko and Ambraseys, 1970; Tchalenko and Berberian, 1975). Meanwhile, more recent studies have focused on the seismology and the active tectonics of Dasht-e Bayaz and surrounding areas in the context of Arabia-Eurasia convergence (Walker et al., 2004; Walker and Jackson, 2004; Walker et al., 2011). However, the main unanswered question regards the role of the E-W sinistral faults such as the Dasht-e Bayaz fault in accommodation of the NNE Arabia - Eurasia convergence (e.g., Vernant et al., 2004; Walpersdorf et al., 2014) between Central Iran and Eurasia. This question can be answered partly through an investigation of the temporal and spatial kinematic evolution of the Dasht-e Bayaz fault and its kinematic interaction with other major structures including the Sistan suture zone. It is also important to know whether the stress field in eastern Iran is due to the stress transfer from the Arabia - Central Iran collision, or is influenced by the geometry and relative motion of individual blocks in eastern Iran (e.g., Jentzer et al., 2017). 
$104 \mathrm{Ma}$ ) in the region affected by the Dasht-e Bayaz fault (Fig. 1); the paleo-tectonic evolution of the area is 105 of course out of the scope of this study. We applied the inversion technique on both kinds of fault slip 106 data as provided through focal mechanism of earthquakes and fault measurements in the field, with well107 known senses and relative chronologies. The level of consistency of our results has been discussed in the 108 light of previous studies on the Cenozoic stress field of the Iranian plateau and surrounding deformation 109 belts. We have then put our results in a larger framework, which we have reconstructed using available 110 kinematic data and results from the east and northeast Iran. This has allowed us to discuss the possible 111 interaction of the Dasht-e Bayaz fault with other active faults of the region. Finally, we have proposed a 112 kinematic scenario to describe the role of strike-slip faulting in the accommodation of active convergence 113 in ENE Iran.

\section{Geodynamic and seismotectonic framework}

According to geological investigations (e.g., Berberian et al., 1999; Walker and Jackson, 2004;

117 Mayer and Le Dortz, 2007; Foroutan et al., 2014) and geodetic Global Positioning System (GPS) 118 measurements (e.g., Vernant et al., 2004; Walpersdorf et al., 2014), the N-striking right-lateral faults in 119 Central Iran, especially on both sides of the Lut block (Fig. 1), accommodate the northward motion of 120 Central Iran relative to Eurasia (Helmand block in Afghanistan). The Distribution of historic records and 121 instrumental earthquake epicenters, as well as the GPS velocity field show that the convergence is mainly 122 accommodated along the block boundaries, while the interior of the blocks (e.g., Lut block) is almost 123 rigid (e.g., Vernant et al., 2004; Walker and Jackson, 2004; Walpersdorf et al., 2014), with low rates of 124 deformation. The crustal-scale dextral shear continues up to the latitude $34^{\circ} \mathrm{N}$, north of which E-W left125 lateral faults like the Dasht-e Bayaz, Niazabad and Doruneh (further north) are present (Fig. 1). At this 126 latitude, the change in geology is accompanied by a change in active faulting from the $\mathrm{N}$-S dextral faults 127 of the Sistan suture zone to a system mainly constituted by E-W sinistral strike-slip faults (e.g., Berberian 
et al., 1999). The role of these crustal faults in the accommodation of active deformation perpendicular to

129 the N-S dextral shear has been a matter of debate since, at least, thirty years ago (e.g. Jackson and 130 McKenzie, 1984; Berberian et al., 1999; Walker and Jackson, 2004; Farbod et al., 2011, 2016; Aflaki et 131 al., 2019). The recent works by Nozaem et al. (2013), Calzolari et al. (2015 and 2016) documented 132 Neogene to Quaternary dextral strike-slip deformation along the NE-SW Kuh-e-Sarhangi and the E-W 133 Kuh-e-Faghan faults and have revealed another complexity in the active kinematics of northwest Lut -

134 Central Iran (Fig. 1). The objective of this part is a brief demonstration of the structural schema and the 135 seismotectonic activity of an active fault network, with complex internal interactions; for this reason we 136 only selected some of the most important and crucial seismic activities in the area without pointing out 137 other subsidiary events that have not been assigned to particular faults.

Active tectonic and seismological studies conducted in Dasht-e Bayaz and the surrounding areas 139 documented that the active faults, responsible for numerous seismic shocks in the area, are temporally and 140 mechanically in close interaction (e.g., Berberian et al., 1999; Walker et al., 2004; Walker et al., 2011). 141 On 31 August 1968, a tremendous destructive earthquake (Mw 7.1) shocked the area and produced a 70 $142 \mathrm{~km}$ E-W coseismic rupture; the maximum coseismic displacement (4.5 m left-lateral and $2.5 \mathrm{~m}$ vertical) 143 was measured in north of the Nimboluk plain (Tchalenko and Ambraseys, 1970; Tchalenko and 144 Berberian, 1975). The formerly called Dasht-e Bayaz fault was renamed later as the western segment of a 145 now longer Dasht-e Bayaz fault, subsequent to the reactivation of its $55 \mathrm{~km}$ length extension to the east. 146 The eastern segment of the Dasht-e Bayaz fault with the same trend and straight geometry attracted 147 attention after 27 November 1979 Mw 7.1 Koli-Buniabad earthquake, only 11 years after the Dasht-e 148 Bayaz main shock (e.g., Berberian et al., 1999).

149 The most remarkable seismic events occurred just 20 hours after the Dasht-e Bayaz main shock 150 during the Ferdows earthquakes of 1st and 4th September 1968 (Mw 6.3 and Mw 5.5, respectively) about $15170 \mathrm{~km}$ west of the Dasht-e Bayaz village. The close proximity (or even overlap) between the domains of 152 impact of the Dasht-e Bayaz and Ferdows earthquakes has prevented researchers from separating their 153 field effects (e.g., Berberian, 2014). Several authors, based on field observations, suggested that the two 
earthquakes occurred on the NW-trending Ferdows reverse fault (Figs. 1 and 2); the reverse focal mechanisms of the earthquakes were also compatible with this fault (see Berberian, 2014 and references therein). After 11 years and during less than one month, three other destructive earthquakes of Korizan (14.11.1979), Koli-Buniabad (27.11.1979 - e.g., Haghipour and Amidi, 1980) and Kalateh Shur (07.12.1979 - e.g., Haghipour and Amidi, 1980; Ambraseys and Melville, 1982) occurred along the northern part of the Abiz fault, the eastern segment of the Dasht-e Bayaz fault and at the intersection of 160 the two faults, respectively. The Zirkuh earthquake of 1997 May 10 (Mw 7.2), caused by the northern 161 segment of the NNW-striking Abiz fault (Fig. 1), has also been considered as the sequence of seismic 162 events triggered by the Dasht-e Bayaz main shock on 31 August 1968 (e.g., Berberian et al., 1999). The 163 125-km-long surface faulting which, with dextral strike-slip mechanism has occurred during the Zirkuh 164 earthquake is known as the longest surface rupture associated with an Iranian earthquake (e.g., Berberian et al., 1999). This NNW-striking fault segment changes into a NNE-SSW strike (causative fault of the November 14, 1979 Korizan earthquake; see above) near the eastern end of the Dasht-e Bayaz fault and provides its dextral pair of a conjugate-like arrangement (see section 4; Fig. 3A). a sequence of earthquakes (e.g. the Zirkuh, Koli-Buniabad and Ferdows earthquakes). The 1968.09.11,

171 1979.01.16 and 1997.06.25 events did not rupture the surface (e.g. Berberian et al., 1999). The 172 1979.01.16 event showed NW-striking reverse faulting and 1997.06.25 event has produced both the 173 possibilities of N-S right-lateral or E-W left-lateral faulting (Berberian et al., 1999). The calibrated 174 relocations and the body-wave modeling of Walker et al. (2011) showed that the epicenter of the 175 1979.01.16 earthquake is centered on an SW-dipping reverse fault. As for the 1997.06.25 event, Walker 176 et al. (2011) also proposed that, through InSAR results, the rupture had occurred on the N-S trending 177 dextral fault plane without the possibility to attribute it to any of the Boznabad or Pavak faults (Fig. 2).

178 Based on this seismicity, it is concluded that the Dasht-e Bayaz and nearby faults are in close 179 kinematic interaction to accommodate the active deformation of the area. This sequence of the Dasht-e- 
Bayaz, Ferdows and Zirkuh earthquakes (occurred between 1968 and 1997) presents one of the most remarkable examples of temporally clustered continental seismicity in the world (e.g., Berberian et al., 1999; Walker et al., 2011). These consecutive destructive earthquakes could have been triggered by the 31 August 1968 Dasht-e Bayaz main shock (e.g., Berberian et al., 1999 and references therein) and occurred along the faults with different kinematics.

\section{Methodology}

\subsection{Inversion of fault-slip data}

Following the method proposed by Carey and Brunier (1974), determination of a deviatoric stress tensor from fault slip data is based on the stress-slip relationship described by Wallace (1951) and Bott (1959). Computer programs, developed for the inversion of fault slip data, compute a mean best fitting deviatoric stress tensor from a group of striated fault planes by minimizing the angular deviation (misfit angle) between the observed striation and the shear stress resolved on the fault plane (Carey and Brunier, 1974, Carey; 1979; Angelier, 1990). The inversion results are revised and refined iteratively to reach the smallest misfit angle while involving the highest possible number of measured homogenous fault slip data. The meaningful process of stress determination (deviatoric reduced stress tensor) from both geological and seismological fault slip data is a delicate challenge requiring good quality of data, meticulous observations and data separation as well as adequate knowledge on both kinematics and mechanics of faulting (see Allmendinger et al., 1989; Shabanian et al., 2010; Hippolyte et al., 2012; Tranos, 2018). A blind use of abundant computer programs (whatever the software is used) seems very simple, but it would lead to mathematic results without geological significance (see Hippolyte et al., 2012 and Tranos, 2018 for details).

The method we used is principally invented (Carey and Brunier, 1974; Carey-Gailhardis and Mercier, 1987) for the analysis of multiphase heterogeneous fault slip datasets measured in natural fault 
outcrops which contain a variety of new created and preexisting fault planes reactivated in distinct stress states. This method easily works with both new created conjugate fault pairs and preexisting faults with unknown geometric relationships and is independent of conjugate fault arrangements for resolving reduced stress tensors (see Carey-Gailhardis and Mercier, 1987 and 1992; Bellier and Zoback, 1995; Regard et al., 2005; Shabanian et al., 2010 for more details). As a main aspect of the program we have used (i.e., FCALC - Geodyn-Soft; Carey-Gailhardis and Mercier, 1987), there is no way for automatic separation of fault slip data and this job have to be done through detailed geological field observations 211 and individual notes on the quality, reliability and chronological relationships (cross-cutting or 212 overprinting) of the structural elements measured in the field, as well as mechanical compatibility of the 213 fault slip data to the resolved stress tensor. Interestingly, the well-known misfit angle, which is an 214 essential criterion for the computer software during the iteration and minimization processes, is the last 215 parameter we consider for the analysis of a heterogeneous fault dataset. This considerably reduces the effect of geologically incompatible slip data in resolving a deviatoric stress tensor. This is simply because 217 an apparently homogenous dataset (separated without reliable geological considerations) could be 218 synthesized through optimizing the misfit angle distribution of the stress model and an arbitrary selection 219 of data mainly based on this criterion. While, that dataset could comprise fault slip data which in reality 220 belong to different tectonic regimes but apparently are compatible with an artificial mean stress tensor 221 resolved from marginal data from those different datasets. Therefore, the misfit angle only shows the 222 level of compatibility of data with a given stress model regardless its geological reliability! Principal inputs are fault-slip data from geological faults measured in the field or seismologically 224 determined focal mechanism of earthquakes including attitudes (e.g., strike/dip/dip quadrant) of striated 225 fault planes and associated striations with well-known sense of movement. As a great advantage, 226 acquisition of field data is feasible almost everywhere and a careful inversion analysis of good quality 227 fault slip data, with known chronological relationships, would lead to a reliable reconstruction of the 228 kinematic history of an area (e.g., Angelier, 1984; Carey-Gailhardis and Mercier, 1992; Hippolyte et al., 229 1993; Bellier and Zoback, 1995; Regard et al., 2005; Shabanian et al., 2010). The main outputs of this 
method are orientations (trend and plunge) of principal stress axes $\sigma 1 \geq \sigma 2 \geq \sigma 3$ (corresponding maximum, 231 intermediate and minimum stresses, respectively) and " $\mathrm{R}=(\sigma 2-\sigma 1) /(\sigma 3-\sigma 1)$ ". This linear parameter (R) 232 equals 1- 1 , $\varphi$ being another commonly used stress ratio (e.g., Angelier, 1979; Zoback, 1989; Ritz and 233 Taboada, 1993), and describes relative stress magnitudes ranging from 0 to 1 (e.g., Carey and Brunier, 234 1974; Mercier et al., 1991; Bellier and Zoback, 1995, Shabanian et al., 2010 and references therein). 235 Different combinations of Andersonian stress arrangements (vertical principal stress axes of $\sigma_{1}, \sigma_{2}$ and $\sigma_{3}$ 236 for pure extensional, strike-slip and reverse faulting, respectively) and $\mathrm{R}$ values lead to various stress 237 regimes responsible for different kinds of faulting (see Ritz and Taboada, 1993; Shabanian et al., 2010 for more details). We used the method originally proposed by Carey (1979); the results deduced from inversion of fault-slip data measured in individual sites along the Dasht-e Bayaz fault and nearby areas are presented in Table 1 (see Figs 3 and 9 for site locations).

\subsection{Relative chronology of fault slip data and data separation}

According to an important assumption accepted in fault kinematic inversion methods, a distinct

244 stress tensor $(\sigma 1 \geq \sigma 2 \geq \sigma 3$ and "R") can create only one slip direction on a given fault plane. The complications of data separation are normally revealed when different sets of heterogeneous fault-slip data are collected from fault planes. Several generations of striae on a single fault plane are surely the result of changes in angular relationships between the fault plane and principal stress axes. Nevertheless, the nature of such changes could either be (1) due to temporal variations in the stress field or (2) could imply the rotation of the fault plane during deformation. In both cases, the chronology of striae is usually determined through the crosscutting relationships of striations and/or fault planes complemented by

251 geological field observations. Except for some probable mistakes in measurements and individual cases of 252 local rotations due to progressive deformation, the fault slip data are usually classified into homogenous 253 sub-groups. In some of related studies, the automatic or semi-automatic methods have also been proposed 254 or utilized to separate heterogeneous fault slip data (e.g., Nemcok and Lisle, 1995; Salvini and 

we preferred to take advantage of techniques concerning data separation based on geological observations and kinematic rules (see Shabanian et al., 2010). Figure 8 shows an example of this strategy which is based on crosscutting relationships, field observations and kinematic considerations. The 10 measurement sites were chosen in outcrops of different stratigraphic ages, ranging from Triassic to Quaternary (Figs 3 and 10); almost half of the measurements (a total number of 170 fault slip data) were done on fault planes

261 affecting Pliocene and Quaternary deposits (see Table 1). Relative chronologies of different generations 262 of striations on a fault plane or in a outcrop has been determined based on the superposition of striations 263 and/or crosscutting relationships between fault planes affecting the outcrop. In a given outcrop, usually, there are few fault planes showing direct chronological indicators for different generations of striations, while the majority of planes only express one direction of striation with unknown relative chronology (see Shabanian et al., 2010 for more details). In such the case, fault slip data of different generations have primarily been separated using the well-known relative chronologies observed in the field and then, other compatible fault planes with only one striation were added to each data set based on their kinematic and mechanical compatibilities with the data set, as well as the geological field notes on each fault plane modern stresses) has been determined considering the age of youngest rock units affected by each stress state and chronological cross-relations between different stress tensors.

Certain criteria should be met in order to determine reliable stress solutions (e.g. Etchecopar, 1984;

274 Carey-Gailhardis and Mercier, 1992; Belier and Zoback, 1995; Shabanian et al., 2010): (1) we need at 275 least 4 fault planes with different attitudes that are well-distributed in the space. A higher number of fault 276 planes and a good spatial distribution will result in a more constrained stress solution, (2) the inversion 277 results will theoretically be reliable when at least 80 percent of deviation angles are under $20^{\circ}$, that means 278 a confidence level of 68 per cent in a Gaussian probability distribution (3) the measured fault planes must 279 show good mechanical compatibility with the stress tensor solution. For instance, a set of transtensional 280 faults cannot be explained by a compressional stress tensor even if output parameters of the tensor to be 
excellent, (4) a reliable stress solution needs fault slip data of good quality; it greatly depends on the

282 details of field observations, the tectonic history of the measurement site and user's experiences of data

283 measurement and inversion analysis. Considering these criteria, A, B and C were assigned to well-

284 constrained, constrained and poorly-constrained stress tensor solutions, respectively. For solutions from

285 less than four well-distributed fault planes, we used a fixed solution (Bellier and Zoback, 1995) in which,

286 one principal stress axis is fixed as vertical. In this study the quality of fixed solutions has been

287 considered the same as $\mathrm{C}$ and they were marked as CF; the stress ratio "R" is not valid for this kind of 288 solutions.

289 According to the abovementioned method, the measured fault slip data were separated into three 290 homogeneous groups of slip generations and were analyzed. This analysis has provided basic information 291 for describing the last kinematic evolution of the Dasht-e Bayaz fault during the Pliocene and Quaternary 292 times. We compared the pattern of kinematic changes along the Dasht-e Bayaz fault with similar studies 293 in nearby regions in E and NE Iran (e.g. Shabanian et al., 2010; Farbod et al., 2011; Javidfakhr et al., 294 2011; Jentzer et al., 2017; Tadayon et al., 2017), which has allowed us to place our results in a larger 295 geodynamic scale (see the discussion).

\subsection{Inversion of earthquake focal mechanism data}

We determined the present-day state of stress in the Dasht-e Bayaz area through the inversion of 299 focal mechanisms of medium to large $(7.1>\mathrm{M}>5.5)$ earthquakes applying the method described by Carey300 Gailhardis and Mercier (1987). These earthquakes have occurred between 1968 and 1997 comprising the 301 Dasht-e Bayaz main shocks. We have only used focal mechanism solutions that had been relocated and 302 modeled using body waves by Walker et al. (2004, 2011). With this method, we analyzed two orthogonal 303 nodal planes for each earthquake focal solution taking into account that only one plane was reactivated 304 during the earthquake due to the regional stress state. The final selection among each pairs of nodal planes 305 can be done by (1) direct observation of the surface rupture of the earthquake, (2) seismological 
investigations of the rupture process, (3) the spatial distribution of aftershocks and (4) the inverse

307 computation by selecting the nodal plane that results in greater consistency with the regional stress field

308 (Carey-Gailhardis and Mercier, 1987). For determining the regional state of stress, the importance of the

309 main shocks (even a single datum) is significantly greater than that of the aftershocks because small

310 earthquakes would probably reflect kinematic instabilities due to heterogeneous deformation and

311 independent faulting in small-scale bodies (e.g. Carey-Gailhardis and Mercier, 1992). For some of the

312 main shocks, we have direct information on the rupture geometry from field observations (Tchalenko and

313 Ambraseys, 1970; Berberian et al., 1999). This serves as a reference for evaluating the compatibility (in a

314 geometric sense) of other events using inverse computation. This method was successfully applied to

315 determine the causative fault plane of the second event of August 2012 earthquake doublet (Mw 6.4, 6.2),

316 that had occurred in the Ahar-Varzaghan complex fault system in NW Iran (see Ghods et al., 2015 and

317 Momeni and Tatar, 2018).

\subsection{Active fault mapping}

During the four last decades, several studies have focused on different aspects of the Dasht-e Bayaz earthquake fault providing structural maps of the fault at different scales and at distinct aims (e.g.,

322 Tchalenko and Ambraseys, 1970; Tchalenko and Berberian, 1975; Walker et al., 2011). However, the

323 specific scope of our study on kinematic aspects of the fault and its interaction with other neighboring

324 main faults has led us to prepare a detailed fault map using the high resolution satellite images (Bing

325 images in SAS Planet, http://sasgis.org; $1 \mathrm{~m}$ resampled pixel size) of the area. A simplified version of this

326 map is shown in Figure 3, while the more detailed maps are centered on the fault terminations and

327 intersection zones (Figs 4-7), where additional information are needed to describe the structural

328 characteristics of the Dasht-e Bayaz fault. Thanks to our new fault mapping, we reinterpreted the

329 structural relationships between the main fault and other structures interacting with from the eastern

330 termination westwards along the Dasht-e Bayaz fault (see below). 


\section{Active tectonics and structure of the Dasht-e Bayaz fault}

The Dasht-e Bayaz fault is a 120-km-long sinistral fault in the north of the Lut block (Fig. 1). The

334 E-W Dasht-e Bayaz fault, with an almost straight geometry, is a structural assemblage of several fault 335 strands with different orientations ranging from $\mathrm{N} 070^{\circ} \mathrm{E}$ to $\mathrm{N} 110^{\circ} \mathrm{E}$ (e.g., Tchalenko and Ambraseys, 336 1970; Fig. 3). This particular structural arrangement forms various contractional and extensional 337 mesoscale structures and the associated morphotectonic landforms such as pull-apart basins, pressure 338 ridges and en-echelon folds at different scales along the fault zone; the same structural patterns were seismically created during the 31 August 1968 Dasht-e Bayaz main shock (Tchalenko and Ambraseys, 1970; Berberian et al., 1999). In addition to these variations in the fault geometry, the Dasht-e Bayaz fault

341 is affected by N-S dextral faults which are in close interaction with the main fault (Figs 3 and 4).

At the eastern end, the Dasht-e Bayaz fault intersects the NNE-striking Korizan segment of the Abiz fault (Fig. 3). As an important verified observation, north of $34^{\circ} \mathrm{N}$, it is difficult to define any

344 relative dominance for the N-S Korizan or the E-W Dasht-e Bayaz faults while south of this latitude, the $345 \mathrm{~N}-\mathrm{S}$ dextral faults are dominant and cut both the E-W sinistral and the NW-SE reverse faults of the region 346 (e.g., Berberian et al., 1999). Near the village of Buniabad in the south of Kheybar Kuh-e Kuchek (i.e., 347 Little Kheybar Mountain), these faults join together into a single ENE-WSW trend (Fig. 3). Farther 348 northeast, however, the sinistral Niazabad fault runs parallel to the Dasht-e Bayaz fault and looks like a 349 left-hand stepping segment in a larger E-W sinistral fault system (Fig. 1), which is apparently dominating 350 the N-S dextral fault system of the Sistan suture. The northern parts of the Korizan fault are partly 351 covered by eolian deposits, while the overall fault trace in the south of Buniabad village (Fig. 3) cuts the 352 Quaternary alluvial fan surfaces. Our mapping of the intersection area shows a deforming wedge between 353 the main traces of the Dasht-e Bayaz and Korizan faults (Fig. 3a); the conjugate arrangement of the main 354 faults implies active contraction inside the wedge. Interestingly, N-S fault traces appear again in a 355 discontinuous way in the northern side of the Dasht-e Bayaz fault trace, cutting through Kheybar Kuh-e 
Kuchek. Except for a few places (see Walker et al., 2011), the N-S fault strands cut the bedrock and there is no way to evaluate their Quaternary activity. Nevertheless, systematic dextral geomorphic offsets of main streams along these faults could indicate their activity during, at least, the Pliocene time.

Another structural node along the Dasht-e Bayaz fault occurs where it intersects with the N-S Mahyar fault (Fig. 4). In fact, the Mahyar fault (e.g. Berberian, 2014) separates the western and eastern earthquake segments of the Dasht-e Bayaz fault (ruptures of the 31 August 1968 and 27 November 1979 earthquakes, respectively). Our detailed mapping of the intersection area (Fig. 4) shows that the crosscutting dextral Mahyar fault and the sinistral Dasht-e Bayaz fault form a typical crosswise (nearly 364 orthogonal) fault arrangement in the middle part of the Dasht-e Bayaz fault trace. These coexisting faults 365 have displaced each other in the sense of their movement of about $1.5 \mathrm{~km}$ (Figs 3 and 4). Following the opposite shear senses of the crosswise faults, double-coupled extensional and contractional domains have been formed in the quarters of this intersection. In the NW and SE extensional quarters, there are two relatively lowlands with an average elevation of $1300 \mathrm{~m}$, while the adjacent NE and SW contractional quarters occupy higher areas with the average elevation of $1400 \mathrm{~m}$ (Fig. 4). The NE contractional quarter fault, southwards (Fig. 4).

In the same area, around the Dasht-e Bayaz and Mahyar faults intersection zone (Fig. 4), different sets of dioritic and andesitic dikes have intruded in folded rocks of Jurassic to Eocene ages (Alavi Naini and Behruzi, 1983; Fauvelet and Eftekhar-Nezhad, 1991). Pliocene deposits cover these post folding dikes and define their stratigraphic age of post Eocene - pre Pliocene. We have mapped 379 dikes through the analysis of Bing Map (SAS Planet(C) satellite images of the area. The clear crosscutting relationships of the dikes show three generations of which the oldest set (microdioritic dikes;

378 Mohammadi Gharetapeh et al., 2014) is the most frequent, with a dominant orientation of $\mathrm{N} 330 \pm 10^{\circ} \mathrm{E}$ 379 (Fig. 4). Two younger minor populations of dikes (pyroxene andesitic with $\mathrm{N} 345 \pm 15^{\circ} \mathrm{E}$ and $\mathrm{N} 10 \pm 10^{\circ} \mathrm{E}$ 380 preferred orientations) are less abundant in the area and clearly cut through the oldest generation where 381 coexisted. 
Our new mapping of the 1979 earthquake rupture reveals that the main trace of the coseismic rupture dies out westward into a N-S reverse fault zone, with a dextral component of faulting (Figs 4 and 5). Other parallel reverse/thrust faults are observed in this quarter, but those haven't been picked up by the coseismic rupture (Fig. 5). In contrast, the adjacent NW extensional quadrant hosts the extensional termination of the 1968 coseismic rupture (Fig. 5). In this area, the E-W trend of the 1968 rupture dies out eastwards into a NE-striking normal fault zone of which a 615-m-long array of surface rupture can be mapped in recent satellite images (Figs 4 and 5). The alignment of several SE-facing landslides (with 389 fresh free-faces recognizable on images) along this part of the rupture is coherent with the extensional 390 character of the rupture termination.

Farther west, the Dasht-e Bayaz fault reaches an E-W, pull-apart basin (the Chah Deraz pull-apart basin), which possesses an elongated shape ( $3900 \mathrm{~m}$ in length and $\sim 870 \mathrm{~m}$ in width), with the length to width ratio of 4.5 . The almond-shaped geometry of the pull-apart basin, in addition to its symmetric curved boundaries (Fig. 6) implies that the basin was formed in a releasing bend (e.g., Dooley and Schreurs, 2012) along the Dasht-e Bayaz fault. Considering the lack of Quaternary activity along the southern border of the basin and the coseismic reactivation of the northern master fault during the 31 August 1968 earthquake (Fig. 6), we suggest that the pull-apart basin has entered a new stage of evolution, by a shift in active extension from the central part to the northwest margin of the basin (Fig. 6). Further to the west, the Dasht-e Bayaz fault controls the contact between Quaternary deposits and Mesozoic sedimentary rocks. In the north of Nimboluk plain, there are outcrops of Miocene marls armored by Quaternary deposits; the dense cultivation and human-made changes in the Quaternary 402 surfaces, cut by the fault, precluded us from following the trace of the coseismic rupture. The detailed 403 rupture maps of Tchalenko and Ambraseys (1970) and Tchalenko and Berberian (1975) show that about $40412 \mathrm{~km}$ westwards from the Chah Deraz pull-apart, the fault trace encounters another structural complexity 405 (Fig. 7). After a 5-km-long en-echelon fracture zone, the main rupture trace turns southwest and continues 406 to the west for $\sim 20 \mathrm{~km}$. This coseismic fault rupture (Mozdabad fault branch) crosses between Dasht-e 407 Bayaz and the Khezri villages and, in the southwest of Mozdabad village, it joins the Ferdows reverse 

Interestingly, the main fault trace, visible in the geomorphology of Quaternary alluvial fans, can be

410 directly traced to the west of the Chah Deraz segment, while only a small part of this Quaternary fault has 411 been reactivated during the 1968 earthquake. This branch of the Dasht-e Bayaz geologic fault continues 412 westwards for 13 kilometers, where it bends towards the northwest and joins the north dipping reverse 413 faults in the middle of Kuh-e Kamarkhid (Fig. 2 and 7A). In that area, a series of en-echelon pressure 414 ridges and folds have been formed due to a restraining curvature along the Dasht-e Bayaz fault (Fig. 7).

415 In summary, our new detailed mapping of the Dasht-e Bayaz fault trace and the related structures 416 (thanks to the available very high resolution satellite images and other facilities) reveals that the Dasht-e 417 Bayaz fault is a complex fault zone in which several fault strands with different orientations and 418 kinematics are actively interacting. In this context, N-S dextral and E-W sinistral faults play a significant role in both the structural pattern and active tectonic deformation along the main fault zone.

\section{Fault kinematics and states of stress in the Dasht-e Bayaz area}

\subsection{Modern state of stress}

The analysis of the youngest group of fault slip data were measured in ten sites (Table 1, Figs 9 and

424 11) including the last coseismic kinematics of the Dasht-e Bayaz fault (for example, sites 2,5 and 6 in Figs $10 \mathrm{a}, 10 \mathrm{e}-\mathrm{f}$ and $10 \mathrm{~h}$, respectively). Except for sites $4,5 \mathrm{~b}$ and 6 , the maximum stress axis $\left(\sigma_{1}\right)$ has the average trend of $\mathrm{N} 045 \pm 5^{\circ} \mathrm{E}$ (Fig. 13C) and the deviatoric stress tensors indicate a homogenous strike-slip stress field in the area including the Dasht-e Bayaz fault (Figs 9 and 11). The trend of the $\sigma_{1}$ axis locally changes in sites $5 b, 6$ and 4 , with an orientation of $\sim \mathrm{N} 070^{\circ} \mathrm{E}$ (see the section 6.1 for more details).

To avoid local stress changes caused by structural rotations in fault zones and local stresses produced at structural complexities such as fault bends, fault relay zones and fault-bend terminations, we

431 have analyzed together the youngest set of fault-slip data only from main fault planes (MFP) measured 
over the study area (Figs 10 and 11). A main fault plain is the most prominent structure which controls overall deformation in a given outcrops (for instance, fault planes marked in Figs 10a, 10c, 10f- j) and is usually distinguished from other subsidiary fault planes in the outcrop during field measurements. The inversion analysis of such a particular data set leads to a mean regional stress state responsible for the reactivation of different main fault planes regardless their geographic location and structural setting. The resulting stress tensor specifies a mean regional strike-slip stress regime characterized by a $\mathrm{N} 42 \pm 05^{\circ} \mathrm{E} \sigma_{1}$ axis (Fig. 11). This regional mean $\sigma_{1}$ axis is very close to the average orientation of $\mathrm{N} 45 \pm 05^{\circ} \mathrm{E}$ for the $\sigma_{1}$ that we have independently obtained in 8 individual sites (Fig. 14C). Almost all the stress tensors (except for sites 5A, 6 and 7) were resolved from the analysis of strike-slip fault planes, with pitch angles less than $20^{\circ}$ (Fig. 11), showing different dextral or sinistral dominant component of faulting in accordance with their orientation with respect to the principal stress axes (Fig. 11). This strike-slip character is also consistent with the regional mean stress tensor deduced from the inversion of main fault planes (MFP in

444 Fig. 14) and is confirmed by the mean $\mathrm{R}$ value of $\sim 0.54$ for the tensors with Andersonian strike-slip arrangement (Fig. 11 and Table 1). Accordingly, a prominent pure strike-slip regime is representative for the modern stress field over the study area.

\subsection{Paleostress state}

In 8 sites along the Dasht-e Bayaz fault, we have observed signatures of the oldest generation of fault slip data. These older data, which were naturally fewer than the younger data, were carefully differentiated and analyzed regarding both our field observations and cross-relation of different individual data in each site. For example, our filed observation in site 7 indicates the signature of two distinct deformation stages in Neogene deposits (Figs 8 and 12). A total number of 20 fault planes were measured in site 7. The SE-striking fault planes show an older dextral reverse kinematics (striation 1 in Fig. 8) 
characterized by a NW-trending maximum compression (Fig. 8C). E-W planes in this data set are oblique-slip dextral reverse faults (right-hand stereogram in Fig. 8C).

In six of eight sites, which are well distributed over the study area, the oldest data sets comprise sufficient data to give independent deviatoric stress tensors (Figs 9 and 12; Table 1). These individual

461 stress tensors represent a paleostress state characterized by a homogeneous $\mathrm{N} 135 \pm 15^{\circ} \mathrm{E}$ trending mean $\sigma_{1}$.

462 As for the dominant stress regime, except for two stress tensors resolved for sites 6 and 7, the other 463 tensors are fixed solutions, with less than four differently oriented fault planes (see the methodology 464 section). In this case, the tensors cannot be used for determining the stress regime. However, the majority 465 of fault planes analyzed in these paleostress tensors is oblique-slip with a dominant reverse component 466 (Fig. 12) and are coherent with a transpressional stress regime as indicated by the B-Quality tensor 7 in 467 Figure 12. In this paleostress regime, the E-W fault planes, which were measured on the earthquake fault trace of Dasht-e Bayaz or on other faults parallel to it, are oblique-slip reverse dextral faults and show a transpressional character (Fig. 8d).

\subsection{Intermediate state of stress}

In addition to these paleo and modern states of stress, the signature of an intermediate stress field stress is characterized by a $\sim 209^{\circ} \mathrm{E}$ mean $\sigma 1$ and a strike slip stress regime (Fig. 14B). However, the insufficient number of stress solutions for this stress state precludes us considering it as an independent regional stress field (see the discussion).

\subsection{The present-day state of stress deducted from inversion of earthquake focal mechanisms}

We have used 15 earthquake focal mechanisms that have been recorded in the Dasht-e Bayaz and nearby areas and have been modeled by Walker et al. $(2004,2011)$ using body wave modeling (Table 2 ).

481 The final stress tensor was resolved through the inversion of fault slip data from several earthquakes 
482 affecting a vast area around the Dasht-e Bayaz fault and is therefore representative of the present-day 483 regional state of stress in the northern Lut block. This solution indicates a single strike-slip tectonic 484 regime, which characterized by a regional $\mathrm{N} 050 \pm 05^{\circ} \mathrm{E}$ trending $\sigma_{1}$ (Fig. 15) responsible for the active 485 deformation (whatever reverse or strike-slip fault mechanism) throughout the region.

\section{Discussion}

\subsection{Regional versus local stress changes in the Dasht-e Bayaz and close vicinity}

In this study, the spatiotemporal changes in the state of stress were investigated through the inversion of fault slip data measured in ten sites along the Dasht-e Bayaz fault. Based on the inversion of

491 independent sets of geologic fault slip data (a $\mathrm{N} 045 \pm 05^{\circ} \mathrm{E}$ compression with strike-slip regime) and 492 earthquake focal mechanisms (a single strike-slip tectonic regime, with a regional $\mathrm{N} 050 \pm 05^{\circ} \mathrm{E}$ trending $493 \sigma_{1}$ ), the present-day state of stress in the Dasht-e Bayaz area is characterized by a mean regional $494 \mathrm{~N} 050 \pm 05^{\circ} \mathrm{E}$ trending $\sigma_{1}$ accommodated by strike-slip tectonics (Fig. 15). The consistency of these results 495 reveals (1) the absence of remarkable change in the modern state of stress during the late Quaternary time, 496 (2) the prevalence of a homogeneous stress field in the brittle crust (above the $\sim 17 \mathrm{~km}$ depth of 497 seismogenic layer) of the Dasht-e Bayaz region and (3) the lack of stress perturbation due to the activity 498 of the Dasht-e Bayaz fault.

The main strike-slip stress regime deduced along the eastern and middle parts of the Dasht-e Bayaz 500 fault changes into a compressional stress regime at the western end of the fault (sites 6 and 7 in Figures 9 501 and 11). These two distinct stress regimes are coherent with different structural settings of the resolved 502 stress tensors. In fact, despite the strike-slip character of the fault that is clearly expressed along its 503 eastern and central portions (e.g., Tchalenko and Ambraseys, 1970), the kinematics of the Dasht-e Bayaz 504 fault changes to oblique-slip sinistral reverse at its western end. In this area, the strike-slip character of the 505 Dasht-e Bayaz fault disappears near the NW-SE Ferdows thrust (Berberian, 1981 and 2014) where the E- 
506 W strike of the fault turns into NW. This change in strike is in accordance with the compressional stress

507 regime obtained from site 7 . As for site 6 , it is inspected along a pressure ridge formed along a branch of

508 the main fault. In that area, the fault branch locally accommodates the contractional deformation induced

509 by left-lateral faulting along the main fault trend. In other words, this compressional stress regime

510 expresses the local variation in regional stress at structural complexities along the fault. Besides these

511 local changes, the paleostress state deduced from the oldest generation of fault slip data measured in

512 Pliocene and older rock units is characterized by a $\mathrm{N} 135 \pm 15^{\circ} \mathrm{E}$ trending mean $\sigma_{1}$, with a transpressional

513 stress regime. During the prevalence of this stress field, the E-W Dasht-e Bayaz fault was an oblique

514 reverse dextral fault.

In the kinematic analysis, an important issue is the possibility of structural rotations due to 516 progressive deformation. Evaluating such a possibility, we have used arrays of dikes intruded in the

517 folded strata of the area (section 4; Fig. 4). Aside for the amazing similarity in trends of the oldest

518 generation of dikes $\left(\mathrm{N} 330 \pm 10^{\circ} \mathrm{E}\right)$ and the paleo- $\sigma_{1}$ we have obtained $\left(\sigma_{\mathrm{hmax}}=\mathrm{N} 315 \pm 15^{\circ} \mathrm{E}\right)$, the overall

519 orientation of the dikes does not significantly vary along and across the strike of both the Mahyar and

520 Dasht-e Bayaz faults (Fig. 4). The same orientations of the first set of dikes close to, and beyond the main

521 fault traces indicates insignificant structural rotations due to the post injection strike-slip faulting.

522 Therefore, in the absence of signs of gradual changes in geological markers like post Eocene dikes (see

523 Figure 4), our results indicate a drastic change in the regional state of stress and in other words, a

524 kinematic switch from dextral to sinistral faulting along the Dasht-e Bayaz fault during the Pliocene-

525 Quaternary time. Currently, the Dasht-e Bayaz main fault zone, reactivated on 31 August 1968, contains

526 several roughly E-W fault strands characterized by a coseismic sinistral mechanism superimposing the

527 older reverse dextral kinematics of the main fault (Figs 8, 11 and 12). 


\subsection{Late Cenozoic stress fields in the Iranian Plateau, Alborz and Kopeh Dagh mountains}

One of the most interesting issues concerning the accommodation of Arabia-Eurasian convergence

531 in the Iranian plateau is the history of the evolution of stress regimes during Pliocene and Quaternary.

532 Thanks to modern techniques, such as the inversion of focal mechanisms of earthquakes, our knowledge

533 about the present-day state of stress has progressed. Whereas, there is still some ambiguity left concerning

534 the interpretation of long-term changes in stress regime and the transition between successive stress 535 regimes.

536 Temporal changes in the stress field of the Alborz range, Kopeh Dagh Mountains and north of the 537 Lut block, as well as northwest Iran have been reported by several authors (e.g., Tchalenko et al., 1974; 538 Abbassi and Shabanian, 1999; Jackson et al., 2002; Allen et al., 2003; Guest et al., 2006; Zanchi et al., 539 2006; Yassaghi and Madanipour, 2008; Abbassi and Farbod, 2009; Landgraf et al., 2009; Shabanian et 540 al., 2010, 2012a; Farbod et al., 2011; Javidfakhr et al., 2011; Tadayon et al., 2017; Aflaki et al., 2018a, 541 2018b). The rate and style of deformation in north and northeast Iran have significantly changed during 542 the late Cenozoic (e.g., Ritz et al., 2006; Shabanian et al., 2009b, 2010). The systematic fault kinematics 543 studies in these regions have shown that the late Cenozoic stress changes had been drastic (e.g., 544 Shabanian et al., 2010; Javidfakhr et al., 2011)

As for temporal changes, Tchalenko et al. (1974), during tectonic studies in the Tehran region, have noticed the possible occurrence of a post-Pleistocene change in the orientation of maximum horizontal 547 compression $\left(\sigma_{1}\right)$ from NW to NE, based on the pattern of post Eocene dikes, the style of folding and 548 faulting in the alluvial formations. In the same region, Abbassi and Shabanian (1999) have found three 549 distinct states of stress and a clockwise rotation in the stress field through the inversion of fault slip data 550 mostly measured in Pliocene-Quaternary alluviums. According to their research, the oldest stress field 551 was characterized by a NW-trending $\sigma_{1}$ that has changed into a N-S and then, into a NE-directed maximum compression affecting late Pleistocene to Holocene alluviums. Another interesting research in west-central Alborz (Axen et al., 2001), has led to the attainment of the first chronological framework for 
a major tectonic reorganization in the Alborz Mountains. They have reported a dextral transpressional movement along main faults parallel with the range (between $56 \mathrm{Ma}$ and $7 \mathrm{Ma}$ ) before onset (ca. $3.4 \mathrm{Ma}$ ) of the modern sinistral faulting on these faults. revealed temporal clockwise changes in the state of stress since 3.6 Ma (Shabanian et al., 2010); those include the horizontal $\sigma_{1}$ oriented $\mathrm{N} 140 \pm 10^{\circ} \mathrm{E}, \mathrm{N} 180 \pm 10^{\circ} \mathrm{E}$ and $\mathrm{N} 30 \pm 15^{\circ} \mathrm{E}$ for the paleo, intermediate and modern states of stress, respectively. Similar drastic temporal changes were reported in NNE Iran,

561 including the eastern Alborz and western Kopeh Dagh mountains (Javidfakhr et al., 2011). The analysis 562 of fault slip data in 48 sites led Javidfakhr et al. (2011) to characterize the three homogenous stress fields 563 as the maximum horizontal stress $\sigma_{1}$ orientated $\mathrm{N} 135 \pm 20^{\circ} \mathrm{E}$ (paleostress), $\mathrm{N} 185 \pm 15^{\circ} \mathrm{E}$ (intermediate) and $564 \mathrm{~N} 36 \pm 20^{\circ} \mathrm{E}$ (modern stress) in the transitional zone between the eastern Alborz and western Kopeh Dagh mountains. Farther south, Farbod et al. (2011) showed that a Pliocene-Quaternary older state of stress, with a $\sigma_{1}$ orientated $\mathrm{N} 150 \pm 20^{\circ} \mathrm{E}$, was changed into a modern maximum compression of $\mathrm{N} 45 \pm 15^{\circ} \mathrm{E}$, responsible for the active sinistral kinematics along the Doruneh fault system.

Other study reveals the same pattern of change in the stress field of northwest Iran (the MianehMahneshan basin; Aflaki et al., 2018a). The NW-trending fold axes in the Upper Red Formation, folded at the end of Middle Miocene, have been overprinted by two younger generations of NE and NW trending folds in a time interval between Pliocene to Quaternary. The inversion results of fault slip data in this 572 region affirm that a compressional paleostress regime (Pliocene-Quaternary), with a $\mathrm{N} 138^{\circ} \mathrm{E}$ trending $\sigma_{1}$, 573 has affected the area before the dominance of the present-day NE-oriented compression.

The recent study in the Sistan belt of eastern Iran (Jentzer et al., 2017), however, obtained three 575 distinct deformation stages during late Cenozoic, including (1) an E-W $\left(\mathrm{N} 087 \pm 5^{\circ} \mathrm{E}\right)$ direction of $\sigma_{1}$ 576 probably in the Late Miocene, (2) a late Pliocene ENE-WSW (N059 $\pm 8^{\circ} \mathrm{E}$ ) direction of $\sigma_{1}$ and (3) a late 577 Pliocene to present-day maximum compression $\left(\mathrm{N} 026 \pm 8^{\circ} \mathrm{E}\right)$. The same authors proposed that during the 578 last $\sim 10-5 \mathrm{Ma}$, the direction of compression has rotated about $60^{\circ}$ counterclockwise in Sistan. The 579 kinematics of this region, especially from the regional geologic and geodynamic points of view, is 
debatable. However, there is no other similar study in the Sistan belt enabling a comparison and the

581 evaluation of the accuracy of their results.

582 In summary, even though several studies confirm the occurrence of drastic changes in the dynamics

583 and consequently, in the kinematics of the north, east and northeastern Iran, these results are

584 geographically sparse and need absolute age-based chronologies in order to drawing firm conclusions on

585 the time of dominance and the geodynamic causes of the change in the context of the Arabia - Eurasia

586 convergence.

\subsection{Integration of our results at the regional scale}

After presenting a brief history of the related studies on the evolution of Late Cenozoic stress state

590 in the north, east and northeast of Iran, here, we put our results in a regional tectonic context in order to

591 evaluate the consistency of the results with other similar studies in the north, northwest and west of the

\section{Dasht-e Bayaz area.}

The results of inversion on both geological and seismological fault slip data indicate the dominance

594 of an active strike-slip tectonic regime characterized by a $\mathrm{N} 45 \pm 05^{\circ} \mathrm{E}$ trending $\sigma_{1}$ in the Dasht-e Bayaz 595 area. There is a good consistency between this stress regime and the modern state of stress with an average compression of $\mathrm{N} 045^{\circ} \mathrm{E}$ reported along the Doruneh fault (Farbod et al., 2011). Farther north,

597 Shabanian et al. (2010) reported a modern state of stress in the Kopeh Dagh and Allah Dagh-Binalud 598 mountains (Fig. 15) characterized by a mean regional $\sim \mathrm{N} 030^{\circ} \mathrm{E}$ trending $\sigma_{1}$ axis. According to the results 599 of Javidfakhr et al. (2011), this modern state of stress prevails on the eastern Alborz and western Kopeh 600 Dagh mountains (mean regional $\sim \mathrm{N} 036^{\circ} \mathrm{E}$ trending $\sigma_{1}$ axis). Interestingly, the results mentioned above 601 cover geological domains with different structural patterns, geological histories and active tectonics, 602 while except for some local perturbations due to structural complexities, the modern state of stress 603 remains homogenous throughout the region. 
As for the intermediate stress regime in the Dasht-e Bayaz area, the related maximum horizontal compression obtained in two sites was oriented as $\sim \mathrm{N} 009^{\circ} \mathrm{E}$. Despite the few number of these stress solutions, at a larger scale, our results are completely in accordance with other studies done in the northeast of Iran (N180 $\pm 10^{\circ} \mathrm{E}$ - Shabanian et al., 2010; Javidfakhr et al., 2011). Although there is no

608 report of intermediate state of stress by Farbod et al. (2011) along the Doruneh fault region, Tadayon et 609 al. (2017) presented structural evidences for the prevalence of a penultimate N-S compression during the 610 Plio-Quaternary time (see also Tadayon et al., 2018).

611 We have obtained a compressional stress regime characterized by a $\mathrm{N} 135 \pm 15^{\circ} \mathrm{E}$ trending mean $\sigma_{1}$ 612 as paleostress state, indicating that the currently left-lateral Dasht-e Bayaz fault had been reverse right613 lateral during a certain period of time. As an example, the coseismic rupture of the 1968 earthquake cuts 614 along the main fault trace at the northern border of the Chah Deraz pull-apart (Figs 3 and 6). In that area, 615 S-shaped sigmoidal lenses within the fault core (Fig. 10d) indicate an older dextral component for the main fault. A similar paleostress state has been reported in the Kopeh Dagh and the transition zone 617 between the Alborz and Kopeh Dagh mountains (N140 $\pm 10^{\circ} \mathrm{E}$ trending $\sigma 1$ - Shabanian et al., 2010; Javidfakhr et al., 2011). A close stress orientation $\left(\mathrm{N} 150 \pm 20^{\circ} \mathrm{E}\right.$ trending $\left.\sigma 1\right)$ and structural configuration were also determined along the Doruneh fault (Farbod et al., 2011; see also Javadi et al., 2013, 2015; Tadayon et al., 2017 and 2018). It is worthy to note that farther west, along the Kuh-e Sarhangi and Kuh-e 621 Faghan faults, Nozaem et al. (2013) and Calzolari et al. (2016 and 2018) have reported a NW-SE directed 622 maximum compression which is responsible for dextral faulting along these faults during the Quaternary 623 time and should not be compared to the paleostress $\sigma_{1}$ direction we are discussing here.

624 The general consistency between the results on the kinematic history of the east, northeast and 625 north of the Arabia-Eurasia collision zone (Abbassi and Shabanian, 1999; Abbassi and Farbod, 2009; 626 Shabanian et al., 2010, 2012b; Farbod et al., 2011; Javidfakhr et al., 2011; Javadi et al., 2013, 2015; 627 Aflaki et al., 2017; Tadayon et al., 2017, 2018; this study) implies a homogenous transfer of stress during 628 different periods of time, regardless of the geodynamic boundaries. Our results confirm that the Zagros 629 collision zone, and its hinterland domain were mechanically coupled during, at least, late Miocene- 
630 Quaternary times (e.g., Tadayon et al., 2018). Such kinds of systematic regional change in the late

631 Miocene to present-day states of stress and kinematics of crustal-scale faults discard the possibility of

632 systematic block rotations around vertical axes in the region between Dasht-e-Bayaz, Doruneh and Kopeh 633 Dagh.

634 Despite the coherency between our results and those obtained in the northern regions, the history of 635 stress changes along the Dasht-e Bayaz fault differs from what is recently obtained along the Sistan 636 Suture zone (Jentzer et al., 2017). Jentzer et al. (2017) presented different sets of fault slip data related to 637 three successive stress states indicating an anticlockwise rotation in the direction of maximum 638 compression from a Late Miocene E-W directed $\sigma 1$ to a late Pliocene to present-day maximum 639 compression directed $\mathrm{N} 026 \pm 8^{\circ} \mathrm{E}$ (see the section 6.2 for more details). Their anticlockwise rotation 640 pattern is contrary to the history we found around the Dasht-e Bayaz and Abiz faults.

As for the age, there is no general consensus on the timing of the aforesaid changes in the stress state; for example, according to the morphotectonic analysis along the Mosha and Taleghan faults in Alborz, Ritz et al. (2006) suggested that the change from a N-S compression (compressional tectonic 644 regime) to the present-day NNE-trending compression should have occurred between 1 and 1.5 Ma. 645 Shabanian et al. (2012a) showed geological evidence for late Cenozoic volcanism (dikes and volcanic 646 domes) coeval with the prevalence of the paleostress state (a NW trending maximum compression) in the 647 transition zone between the Kopeh Dagh and Binalud mountains. The last phase of volcanism was dated 648 at 2.4 Ma (Ar-Ar dating of dacitic volcanic domes) and subsequently, a volcanic dome has been right649 laterally displaced by the N-S Chakaneh Fault, reactivated in the modern stress state (Shabanian et al., $6502009 \mathrm{~b}, 2012 \mathrm{a}$ ). Accordingly, they proposed a maximum age of $2.4 \mathrm{Ma}$ (close to the border of Pliocene 651 and Quaternary) for the end of the paleostress prevalence. In the Mahneshan area (NW Iran; Fig. 15), 652 Aflaki et al. (2018a) proposed that the last drastic change in the stress regime into the present-day stress 653 state (a NE trending maximum compression) has taken place at the Pliocene-Quaternary boundary. 654 Around the Doruneh fault (north of the Lut Block), however, Tadayon et al. (2018) suggested that the 655 switch from an early NW-oriented $\sigma_{1}$ to the penultimate N-S maximum compression has occurred at the 
Miocene-Pliocene boundary (5-6 Ma) and this change has been the source of an important cooling/exhumation in the area.

Nowadays, a drastic change in the Plio-Quaternary tectonic regime throughout the Iranian plateau and the surrounding deformation domains is a geological fact, thanks to different researches carried out

660 during the last two decades (e.g., Abbassi and Shabanian, 1999; Regard et al., 2005; Shabanian et al., 661 2010, 2012a; Javidfakhr et al., 2011; Farbod et al., 2011; Tadayon et al., 2017; Jentzer et al., 2017; Aflaki 662 et al., 2018a). The regional extent of these similar changes in distant Pliocene-Quaternary stress fields 663 clearly discards the possibility of block/stress rotation during progressive deformation. However, the 664 possible causes of change in stress regime, especially in E and $\mathrm{N}$ of Iran, remains unclear. This change 665 may be due to the onset of the northward subduction of the South Caspian Basin, and/or changes in the 666 structural configuration or in the lithospheric characteristics of $\mathrm{N}$ and $\mathrm{NE}$ Iran during an evolving collisional convergence (Shabanian et al., 2012a). In other words, it may correspond to a major regional reorganization of the plate boundary, following the transition from an infant to a mature stage of continental collision (Tadayon et al., 2018).

\subsection{Tectonic scenario and kinematic model}

According to the model frequently applied in the east and northeast of Iran, originally proposed by Jackson and McKenzie, (1984), an uneven distribution of N-S right-lateral shear between Central Iran and

674 Afghanistan and its westward decrease caused a clockwise rotation of fault bounded blocks north of $675 \sim 34^{\circ} \mathrm{N}$ (Walker et al., 2004; Walker and Jackson, 2004). The model tends to explain the structural features of the northern Lut block by the concept of clockwise rotation around vertical axes (for the basic assumptions of the model see Farbod et al., 2011). This block rotation model was questioned about its lack of ability in explaining the prominent curvature and the other complexities along the Doruneh Fault System (see Farbod et al., 2011 for detail). For example, Farbod et al. (2011), showed that to attain the 
counterclockwise in the western part. It is noteworthy that structural deflections and internal deformation, due to local dragging or compression caused by faults or thrust zones, have usually been interpreted as systematic block rotations around vertical axes (e.g., Walker et al., 2004).

The occurrence of pre-Pliocene dextral faulting on E-W trends distributed across Central Iran (Javadi et al., 2013, 2015; Nozaem et al., 2013; Bagheri et al., 2016; Calzolari et al., 2016, 2018; Tadayon et al., 2017) and the Quaternary kinematic shifts along the Doruneh and Dasht-e Bayaz faults (Farbod et al., 2011; Javadi et al., 2015; this study), which clearly indicate a homogenous regional stress field distribution and coeval evolution of the intracontinental deformation in Central Iran, are not coherent with the block rotation model (see Tadayon et al., 2018 for discussion). The paleomagnetic data of Mattei et al. (2012) also do not show any systematic clockwise rotation over the Neogene in the region. The most recent study by Mattei et al. (2019) provides new paleomagnetic data on the Kopeh Dagh. They report that paleomagnetic rotations (the mean of $11.3 \pm 9.4^{\circ}$ clockwise rotation) occurred in the Kopeh Dagh belt between $\sim 6-4 \mathrm{Ma}$ and $\approx 2 \mathrm{Ma}$, before the onset of the westward extrusion of the South Caspian Block. In their studies, Mattei et al. (2017 and 2019) also emphasize that their oroclinal model does not correspond to the present-day kinematics of the studied areas (Alborz and Kopeh Dagh) and the rotation was stopped before the onset of the present-day kinematics at $\sim 2 \mathrm{Ma}$.

In our tectonic scenario (Figs 16 and 17), right-lateral shear is considered as the main mechanism for the accommodation of the Arabia-Eurasia convergence, but it is not necessarily the case everywhere in $\mathrm{E}$ and NE Iran. As for the Lut block, the GPS velocity vectors show a northward (N013 $\left.{ }^{\circ} \mathrm{E}\right)$ block motion with respect to Eurasia (Walpersdorf et al., 2014). In the north of latitude of $34^{\circ} \mathrm{N}$ (corresponding to the E-trending Dasht-e Bayaz fault), the N-S right-lateral shear interrupts and does not continue to the north. Beyond this latitude, the convergence is mainly accommodated by crustal shortening across NW-trending reverse/thrust faults. The Ferdows reverse fault zone, the Jangal and Khaf thrust faults and the eastern reverse termination of the Doruneh fault (Farbod et al., 2011) as well as the restraining fault terminations in the southern flank of Binalud (Shabanian et al., 2012b) and the Fariman area (Aflaki et al., 2019) are 
among the most important NW-striking reverse faults confirming our tectonic scenario in northeastern Iran.

To the north and approximately at the latitude $36^{\circ} \mathrm{N}$, the right-lateral shear gradually appears along the NE boundary of the Arabia - Eurasia collision zone and involves the NNW-trending faults (instead of the N-S dextral faults to the south) going through the Kopeh Dagh Mountains. The distance between these

711 two fault systems is occupied by a soft-linking restraining relay zone (Binalud-Fariman-Torbat-e Jam;

712 Aflaki et al., 2019) in which the mechanism of faulting is preferably reverse to revers dextral, while 713 farther north in the Kopeh Dagh, it is pure dextral strike-slip. In other words, the N-S right-lateral shear 714 between Iran and Afghanistan that had been interrupted in the latitude $34^{\circ} \mathrm{N}$ (corresponding to the Dasht715 e Bayaz fault) is recuperated gradually around the latitude of $\sim 36^{\circ} \mathrm{N}$, but this time along the NW-trending 716 faults and against the Turan platform instead of the Helmand block (Afghanistan). the area affected by the 5th April 2017 Sefid Sang earthquake (Mw 6), showed that the dextral shear along the NNW-striking faults (i.e., Bakharden-Quchan and Hezar Masjed fault systems) is transferred southeast into WNW-striking transpressional terminations in the region between the Binalud Mountains and Doruneh fault (Fig. 17). The CMT and the first polarity solutions of the main shock and the two aftershocks of this seismic event, which occurred close to the southern termination of the Hezar Masjed fault system near the town of Fariman (Fig. 15), indicate a mainly reverse mechanism with a small dextral component (See Aflaki et al., 2019 for details). This event clearly reveals the dominance of reverse faulting in the southeastern end of Kopeh Dagh and the eastern termination of the Doruneh fault.

In summary, we suggest that the outstanding changes in the structural pattern of these regions are the cause of a significant change in the accommodation mechanism of convergence. It means major fault 728 zones in the $\mathrm{E}$ and NE Iranian regions guide and control lithospheric block motions and their related 729 velocity fields. In the offset and/or overlapping areas of these major fault zones the convergence is 730 accommodated by internal deformation and shortening through reverse/thrust faulting and active folding 
731 (e.g., Farbod et al., 2011; Aflaki et al., 2019). For instance, the pure strike-slip Doruneh fault becomes a 732 typical reverse fault at its eastern end parallel to the other NW-trending reverse faults such as Ferdows, 733 Khaf and Jangal. In this context the role of E-W sinistral faults such as the Doruneh, Dasht-e Bayaz and 734 Niazabad faults can be explained through their setting in the regional structural pattern.

The Khaf and Jangal thrusts have been considered as probable sources for the Zuzan historical destructive earthquakes (Berberian, 2014) of 19 and 21 October of 1336 A.D., respectively. The 1 and 4

737 September 1968 Ferdows earthquakes $\left(\mathrm{M}_{\mathrm{W}} 6.8\right.$ and $\left.\mathrm{M}_{\mathrm{W}} 5.5\right)$ also indicate significant tectonic activity of 738 these reverse fault zone. The study of magnetic foliation vertical and oblique to the bedding of post 739 Miocene folds in the Ferdows fault zone (Rashid et al., 2015) suggests that a cleavage system, not visible 740 at the outcrop scale, has been developed as a consequence of recent shortening related to the activity of 741 this thrust zone. All these observations reveal that, in the northern Lut, the NW-trending reverse/thrust 742 fault zones accommodates substantial portion of the active deformation perpendicular to their strikes. The 743 E-W strike-slip faults such as the Dasht-e Bayaz and Niazabad faults therefore retain their complementary 744 role in the crustal shortening between these thrust zones (Fig. 2). It is worth mentioning that our 745 kinematic model generally describes the northeastern border of Arabia-Eurasia collision zone and clearly 746 it does not include the distant regions such as the eastern Alborz and internal blocks of Central Iran.

Summarizing all these observations on both the structural configuration and the present-day relative velocity field (Eurasia fixed) in east-northeast Iran, the Doruneh fault is a major boundary separating two distinct northern and southern domains (Fig. 16). Angular relationships between N-S dextral and E-W 750 sinistral faults obviously change in these tectonic domains such that the northern domain is characterized 751 by NNW-striking dextral and ENE-striking sinistral faults (e.g., Tchalenko and Berberian, 1975; 752 Shabanian et al., 2009a, 2010; Javidfakhr et al., 2011), while, N-S dextral, E-W sinistral and NW-SE 753 reverse/thrust faults are dominant in the southern domain. These different structural patterns lead to (1) 754 the NNW extrusion of both Central Iran and western Kopeh Dagh towards the South Caspian Basin 755 (Hollingsworth et al., 2006; Shabanian et al., 2009b) and (2) block translation and internal deformation 
through crosswise strike-slip faulting accompanied by reverse/thrust faulting in confining wedge in the north and south of the Doruneh fault, respectively.

The details of these different processes are shown in Figure 17. The process of wedge confining at the edges of north-going blocks (Fig. 17a; due to a NE-trending compression) allows accommodating the internal deformation not absorbed by the lithospheric scale northwards motion of Central Iran relative to

761 Eurasia. The block adjustment requiring for the accommodation of this internal deformation is done 762 through crosswise faulting along N-S dextral and E-W sinistral faults (Fig. 17b-d). The active crosswise 763 pattern of the faults and the almost symmetrical deformation in the four quadrants around their 764 intersection zones (Figs 4 and 17) indicate the same structural significance for the N-S and E-W faults. However, the simultaneous activity of these crosswise fault sets is mechanically impossible; therefore, the fault sets must be operating in sequence (e.g., Freund, 1974). The sequence of recent seismic activities,

767 producing sinistral faulting along both the western and eastern segments of the Dasht-e Bayaz fault and 768 right-lateral faulting in the south of this system, could confirm this interaction (see Berberian et al., 1999;

769 Walker et al., 2011). This active crosswise faulting also leads to the development of contractional 770 (reverse/thrust) fault zones perpendicular to the overall direction of Arabia - Eurasia convergence 771 accommodating two northward and eastward components of the convergence (Fig. 17).

We emphasize that this tectonic scenario is based on different geological and seismological 773 observations (this study and the references cited above) on the eastern and northeastern boundaries of the Arabia - Eurasia convergence zone. We do not apply this scenario to kinematic complexities reported in other places in Central Iran. For example, dextral faulting along the Kuh-e Sarhangi and Kuh-e Faghan faults in the northwest margin of the Lut block (Nozaem et al., 2013; Calzolari et al., 2016 and 2018) has

777 been explained as a consequence of an excess dextral shear generated in the intrafault block bordered by 778 the Doruneh fault to the north and the Dasht-e-Bayaz fault to the south. In this context, the Ferdows 779 reverse fault zone partly accommodates internal deformation of the intrafault block (Nozaem et al., 2013). 780 At first glance to our tectonic scenario, one may make a similar conclusion by assuming a component of 
westward extrusion for the northern block of the Dasht-e Bayaz fault. However, deducing such the

782

783

conclusion needs detailed information on the difference of slip rates on the Doruneh and Dasht-e Bayaz faults as well as the contribution of the Ferdows reverse fault zone in the accommodation of this differential slip rate.

\section{Conclusion}

Our inversion analysis of fault kinematics data revealed signatures of three distinct stress fields in the Dasht-e Bayaz area during Plio-Quaternary. Before the onset of the active left-lateral faulting along the Dasht-e Bayaz fault, an old stress state characterized by a $\mathrm{N} 135 \pm 15^{\circ} \mathrm{E}$ trending $\sigma_{1}$ was responsible for the dextral transpressional movements. The consistency between the inversion results of both modern geological fault slip data and the earthquake focal mechanisms reveals: (1) the absence of remarkable change in the modern state of stress during the late Quaternary time, (2) the prevalence of a homogeneous stress field in the brittle crust (above the $\sim 17 \mathrm{~km}$ depth of seismogenic layer) of the Dasht-e Bayaz region and (3) the lack of long-term stress perturbation due to the activity of the Dasht-e Bayaz fault.

Our observations indicate that the kinematic changes during the Pliocene - Quaternary times have not been restricted to the northeastern part of the Iranian plateau. The general consistency between the results on the kinematic history of the east, northeast and north of the Arabia - Eurasia collision zone implies that a homogenous transfer of stress during, at least, late Miocene - Quaternary times, has taken place due to the mechanical coupling of the Zagros collision and its hinterland domains.

We suggest that the region between Lut and Kopeh Dagh is divided by the Doruneh fault into two northern and southern distinct tectonic domains. The northern domain is characterized by the extrusion of fault-bounded blocks towards the north-northwest, while in the southern domain, the northward motion of the central Iranian blocks occurs through structural and kinematic interactions between N-S dextral, E-W sinistral and NW-striking reverse/thrust faults at the block boundaries without a need for symmetric block rotations around vertical axes. 


\section{Acknowledgements}

We would like to thank to Mr. Koreie and Mr. Fotovati from Geological Survey of Iran for their support and logistic assistance. We are grateful to municipality of Khezri-Dasht-e Bayaz and Sangan Iron Ore Complex for their support during field trips. We thank Mr. Lhôte and the staff of French Embassy in Tehran. We appreciate to A. Ghods and F. Sobouti in Institute for Advanced Studies in Basic Sciences in Zanjan. Very careful and insightful reviews by Federico Rossetti and two anonymous reviewers have greatly improved the manuscript. We are indebted to Editor Ling Chen for handling the manuscript.

\section{References}

Abbassi M.R., and E. Shabanian (1999), Evolution of the stress field in the Tehran region during the Quaternary, Third International Conference on Seismology and Earthquake Engineering, TehranIran.

Abbassi, M.R., and Y. Farbod (2009), Faulting and folding in quaternary deposits of Tehran's piedmont (Iran), Journal of Asian Earth Sciences, 34, 522-531, doi:10.1016/j.jseaes.2008.08.001.

Aflaki, M., Shabanian, E., and Z. Davoodi (2017), Quaternary state of stress in the Mahneshan-Mianeh sedimentary basin, NW Iran, Scientific quarterly of Geoscience, Text in Persian with English abstract, 26, 102,

Aflaki, M., Shabanian, E., and Z. Davoodi (2018a), Signatures of Deformation Related to the PlioQuaternary State of Stress in the Mahneshan-Mianeh Basin (NW Iran), Iranian J. of Seismology and Earthquake Engineering, Text in Persian with English abstract, $4^{\text {th }}$ year, 4, $29-42$.

Aflaki, M., Ghods, A., Mousavi, Z. , Shabanian, E., Vajedian, S., and M. Akbarzadeh (2018b), Seismotectonic characteristics of the 2017 Sefid Sang (Mw 6) earthquake, The 18th Iranian Geophysical Conference, 1-4. 
Aflaki, M., Mousavi, Z., Ghods, A., Shabanian, E., Vajedian, S., and M. Akbarzadeh (2019), The 2017 Mw 6 Sefid Sang earthquake and its implication for the geodynamics of NE Iran, Geophysical Journal International, 218(2), 1227-1245, DOI: 10.1093/gji/ggz172/5462654.

Alavi Naini, M., and A. Behruzi (1983), Geological quadrangle map of Iran, Map K-6, Gonabad sheet, scale 1:250,000, Geological Survey of Iran, Tehran.

Allen, M.B., Ghassemi, M.R., Shahrabi, M., and M. Qorashi (2003), Accommodation of late Cenozoic oblique shortening in the Alborz range, northern Iran, J. Struct. Geol., 25, 659-672.

Allmendinger, R.W., Strecker, M., Eremchuk, J.E., and P. Francis (1989), Neotectonic deformation of the southern Puna plateau, NW Argentina, J. S. Am. Earth Sci., 2, 111-130.

Allmendinger, R.W., Cardozo, N., and D., Fisher (2013), Structural geology algorithms: Vectors and tensors in structural geology, Cambridge University Press.

Ambraseys, N.N., and J.S. Tchalenko (1969), The Dasht-e-Bayaz (Iran) earthquake of August 31, 1968: A field report, Bull. Seism. Soc. Am., 59, 1751-1792.

Ambraseys, N.N., and C.P. Melville (1982), A history of Persian earthquakes, Cambridge University Press, Cambridge.

Angelier, J., (1979), Determination of mean principal stresses for a given fault population, Tectonophysics, 56, T17-T26.

Angelier, J., (1984), Tectonic analysis of fault slip data sets, J. Geophys. Res., 89, 5835-5848.

Angelier, J., (1990), Inversion of field data in fault tectonics to obtain the regional stress. III-a new rapid direct inversion method by analytical means, Geophys. J. Int., 103, 363-376. 
Authemayou, C., Chardon, D., Bellier, O., Malekzade, Z., Shabanian, E., and M. Abbassi (2006), Late Cenozoic partitioning of oblique plate convergence in the Zagros fold-and thrust belt (Iran), Tectonics, 25, TC3002, doi:10.1029/2005TCOO1860.

Authemayou, C., Bellier, O., Chardon, D., Benedetti, L., Malekzade, Z., Claude, C., Angeletti, B., Shabanian, E., and M.R. Abbassi (2009), Quaternary slip-rates of the Kazerun and the Main Recent Faults: active strike-slip partitioning in the Zagros fold and-thrust belt, Geophys. J. Int., 178, 524-540, doi:10.1111/j.1365-246X.2009.04191.x.

Axen G.J., Lam, P.S., Grove, M., Stockli, D.F., and J. Hassanzadeh (2001), Exhumation of the westcentral Alborz Mountains, Iran, Caspian subsidence, and collision-related tectonics, Geology, 29, $559-562$.

Bagheri, S., Madhanifard, R., and F. Zahabi (2016), Kinematics of the Great Kavir fault inferred from a structural analysis of the Pees Kuh Complex, Jandaq area, central Iran, Geological Society of America Special Papers, 525, doi:10.1130/2016.2525.

Bellier, O., and M.L. Zoback (1995), Recent state of stress change in the Walker Lane zone, western Basin and Range province, United States, Tectonics, 14, 564-593, doi:10.1029/94TC00596.

Berberian, M., (1981), Active faulting and tectonics of Iran, In: Gupta H.K., and F.M. Delany (Editors) Zagros, Hindu Kush, Himalaya Geodynamic Evolution, Am. Geophys. Union, Geodyn. S. 3, 33-69, doi:10.1029/GD003.

Berberian, M., (1995), Natural Hazards and the First Earthquake Catalogue of Iran, Volume 1: Historical Hazards in Iran Prior to 1900, Int. Inst. Earthq. Eng. \& Seismology, Tehran, Iran.

Berberian, M., Jackson, J.A., Qorashi, M., Khatib, M.M., Priestley, K., Talebian, M., and M. GhafuriAshtiani (1999), The 1997 May 10 Zirkuh (Qa'enat) earthquake (Mw 7.2): faulting along the Sistan suture zone of eastern Iran, Geophys. J. Int., 136, 671-94, doi:10.1046/j.1365-246x.1999.00762.x. 
Berberian, M., (2014), Earthquakes and Coseismic Surface Faulting on the Iranian Plateau, Elsevier, Developments in Earth Surface Processes, 17, 2-714.

Bott, M.H.P., (1959), The mechanics of oblique slip faulting, Geol. Mag. 96, 109-117.

Braud, J., and L.E. Ricou (1975), Eléments de continuité entre le Zagros et la Turquie du Sud-Est, Bulletin de la Société Géologique de France, 17, 1015-23.

Burg, J.-P., (2018), Geology of the onshore Makran accretionary wedge: Synthesis and tectonic interpretation, Earth-Science Reviews, 185, 1210-1231, doi:10.1016/j.earscirev.2018.09.011.

Calzolari, G., Rossetti, F., Della Seta, M., Nozaem, R., Olivetti, V., Balestrieri, M.L., Cosentino, D., Faccenna, C., Stuart, F.M., and G. Vignaroli, (2015), Spatio-temporal evolution of intraplate strikeslip faulting: The Neogene-Quaternary Kuh-e-Faghan Fault, central Iran, Geol. Soc. Am. Bull., 128, 374-396, doi:10.1130/B31266.1.

Calzolari, G., Della Seta, M., Rossetti, F., Nozaem, R., Vignaroli, G., Cosentino, D., and C. Faccenna (2016), Geomorphic signal of active faulting at the northern edge of Lut Block: Insights on the kinematic scenario of Central Iran, Tectonics, 35, 76-102, doi:10.1002/ 2015TC003869.

Calzolari, G., Rossetti, F., Ault, Alexis K., Lucci, F., Olivetti, V., and R. Nozaem (2018), Hematite (UTh)/He thermochronometry constrains intraplate strike-slip faulting on the Kuh-e-Faghan Fault, central Iran, Tectonophysics, 728-729, 41-54, doi:10.1016/j.tecto.2018.01.023.

Carey, E., and B. Brunier (1974), Analyse théorique et numérique un modèle mécanique élémentaire appliqué à l'étude d'une population de failles, C. R. Acad. Sci., 279, 891-894.

Carey, E. (1979), Recherche des directions principales contraintes associées au jeu d'une population de failles, Rev. Geol. Dyn. Geogr. Phys., 21, 57 - 66. 
892

893

Carey-Gailhardis, E., and J.L. Mercier (1987), A numerical method for determining the state of stress using focal mechanisms of earthquake populations: application to Tibetan teleseisms and microseismicity of Southern Peru, Earth Planet. Sci. Lett., 82, 165-179.

Carey-Gailhardis, E., and J.L. Mercier (1992), Regional state of stress, fault kinematics and adjustments of blocks in a fractured body of rocks: application to the microseismicity of the Rhine graben, J. Struct. Geol., 14, 1007-1017.

Cisternas, A., and H. Philip (1997), Seismotectonics of the Mediterranean region and the Caucasus, In: Giardini, D., and S. Balassanian (Editors), Historical and Prehistorical Earthquakes in the Caucasus, Kluwer Academic Publishing, Dordrecht, Netherlands, 39-77.

Dooley T.P., and G. Schreurs (2012), Analogue modelling of intraplate strike-slip tectonics: A review and new experimental results, Tectonophysics, 574-575, 1-71.

Etchecopar, A., (1984), Etude des états de contraintes en tectonique cassante et simulation de deformations plastiques (approche mathématique), thèse d'Etat, Université Montpellier II, France.

Farbod, Y., Bellier, O., Shabanian, E., and M.R. Abbassi (2011), Geomorphic and structural variations along the Doruneh Fault System (Central Iran), Tectonics, 30, TC6014, doi:10.1029/2011TC002889.

Farbod, Y., Shabanian, E., Bellier, O., Abbassi, M. R., Braucher, R., Benedetti, L., Bourles, D., and K. Hessami (2016), Spatial variations in late Quaternary slip rates along the Doruneh fault system (central Iran), Tectonics, 35, 386-406.

Fauvelet, E., and J. Eftekhar-Nezhad (1991), Geological quadrangle map of Iran, Map K-7, Qayen sheet, scale 1:250,000, Geological Survey of Iran, Tehran.

Foroutan, M., Meyer, B., Sébrier, M., Nazari, H., Murray, A.S., Le Dortz, K., Shokri, M.A., Arnold, M., Aumaître, G., Bourlès, D., Keddadouche, K., Solaymani-Azad, S., and M.J. Bolourchi (2014), Late 
914

915

916

917

918

919

920

921

922

923

924

925

926

927

928

929

930

931

932

933

Pleistocene-Holocene right slip rate and paleoseismology of the Nayband fault, western margin of the Lut block, Iran, J. Geophys. Res., 119, 3517-3560, doi:10.1002/2013JB010746.

Freund, R., (1974), Kinematics of transform and transcurrent faults, Tectonophysics, 21, 93-134.

Fry, N., (1999), Striated faults: visual appreciation of their constraint on possible paleostress tensors, J. Struct. Geol., 21, 7-21.

Ghods, A., Shabanian, E., Bergman, E., Faridi, M., Donner, S., Mortezanejad, G., and A. Aziz-Zanjani, (2015), The Varzaghan-Ahar, Iran, Earthquake Doublet ( $\mathrm{Mw}$ 6.4, 6.2): implications for the geodynamics of northwest Iran, Geophys. J. Int., 203, 522-540, doi:10.1093/gji/ggv306.

Guest, B., Stockli, D.F., Grove, M., Axen, G.J., Lam, P.S., and J. Hassanzadeh (2006), Thermal histories from the central Alborz mountains, northern Iran: implications for the spatial and temporal distribution of deformation in northern Iran, Geol. Soc. Am. Bull., 118, 1507-1521.

Haghipour, A., and M. Amidi (1980), The November 14 to December 25, 1979, Ghaenat earthquakes of northeast Iran and their tectonic implications, Bull. Seism. Soc. Am., 70, 1751-1757.

Heidbach, O., Rajabi, M., Reiter, K., Ziegler, M., and WSM Team (2016), World Stress Map Database Release, GFZ Data Services, doi:10.5880/WSM.2016.001.

Hessami, K., Jamali, F., and H. Tabassi (2003), Major active faults of Iran, scale 1:2,500,000, International Institute of Earthquake Engineering and Seismology, Iran-Tehran.

Hippolyte, J.-C., Angelier, J., Nury, D., Bergerat, F., and G. Guieu (1993), Tectonic-stratigraphic record of paleostress time changes in the Oligocene basins of the Provence, southern France, Tectonophysics, 226, 15-35. 
934

935

936

937

938

939

940

941

942

943

944

945

946

947

948

949

950

951

952

953

954

955

956

Hippolyte, J.-C., Bergerat, F., Gordon, M.B., Bellier, O., and N. Espurt (2012), Keys and pitfalls in mesoscale fault analysis and paleostress reconstructions, the use of Angelier's methods, Tectonophysics, 581, 144-162, doi:10.1016/j.tecto.2012.01.012.

Hollingsworth, J., Jackson, J., Walker, R.T., Gheitanchi, M.R., and M.J. Bolourchi (2006), Strike-slip faulting, rotation and along-strike elongation in the Kopeh Dagh Mountains, NE Iran, Geophys. J. Int., 166, 1161-1177, doi:10.1111/j.1365-246X.2006.02983.x.

Jackson, J., and D. McKenzie (1984), Active tectonics of the Alpine-Himalayan belt between Turkey and Pakistan, Geophys. J. R. astr. Soc., 77, 185-264.

Jackson, J., Priestley, K., Allen, M., and M. Berberian (2002), Active tectonics of the South Caspian Basin, Geophys. J. Int., 148, 214-245.

Javadi, H.R., Ghassemi, M.R., Shahpasandzadeh, M., Guest, B., Esterabi-Ashtiani, M., Yassaghi, A., and M. Kouhpeyma (2013), History of faulting on the Doruneh Fault System: Implications for the kinematic changes of the Central Iranian Microplate, Geol. Mag., 150, 651-672, doi:10.1017/s0016756812000751.

Javadi, H.R., Esterabi-Ashtiani, M., Guest, B., Yassaghi, A., Ghassemi, M.R., Shahpasandzadeh, M., and A. Naeimi (2015), Tectonic reversal of the western Doruneh Fault System: Implications for Central Asian tectonics, Tectonics, 34, doi:10.1002/2015TC003931.

Javidfakhr, B., Bellier, O., Shabanian, E., Ahmadian, S., and A., Saidi (2011), Plio-Quaternary tectonic regime changes in the transition zone between Alborz and Kopeh Dagh mountain ranges (NE Iran), Tectonophysics, 506, 86-108, doi:10.1016/j.tecto.2011.04.013.

Jentzer, M., Fournier, M., Agard, P., Omrani, J., Khatib, M. M., and H. Whitechurch (2017), Neogene to Present paleostress field in Eastern Iran (Sistan belt) and implications for regional geodynamics, Tectonics, 36, 321-339, doi:10.1002/2016tc004275. 
962

963

964

965

966

967

968

969

970

971

972

973

974

975

976

977

Karakhanian, A.S., Trifonov, V.G., Philip, H., Avagyan, A., Hessami, K., Jamali, F., Salih Bayraktutan, M., Bagdassarian, H., Arakelian, S., Davtian, V., and A. Adilkhanyan, (2004), Active faulting and natural hazards in Armenia, eastern Turkey and northwestern Iran, Tectonophysics, 380,189-219, doi:10.1016/j.tecto.2003.09.020.

Landgraf, A., Ballato, P., Strecker, M.R., Friedrich, A., Tabatabaei, S.H., and M. Shahpasandzadeh (2009), Fault-kinematic and geomorphic observations along the North Tehran Thrust and Mosha Fasham Fault, Alborz mountains Iran: implications for fault-system evolution and interaction in a changing tectonic regime, Geophys. J. Int. 177, 676-690, doi:10.1111/j.1365-246X.2009.04089.x.

Marrett, R. A., and R.W. Allmendinger (1990), Kinematic analysis of fault-slip data, J. Struct. Geol., 12, 973-986.

Mattei, M., Cifelli, F., Muttoni, G., Zanchi, A., Berra, F., Mossavvari, F., and S.A. Eshraghi (2012), Neogene block rotation in Central Iran: Evidence from paleomagnetic data, Geol. Soc. Am. Bull., 124, 943-956, doi:10.1130/B30479.1.

Mattei, M., Cifelli, F., Alimohammadian, H., Rashid, H., Winkler, A., Sagnotti, L. (2017), Oroclinal bending in the Alborz Mountains (northern Iran): new constraints on the age of South Caspian subduction and extrusion tectonics, Gondwana Research 42, 13-28. https://doi.org/10.1016/j.gr.2016.10.003.

Mattei, M., Visconti, A. L., Cifelli, F., Nozaem, R., Winkler, A. and Sagnotti L. (2019), Clockwise paleomagnetic rotations in northeastern Iran: Major implications on recent geodynamic evolution of outer sectors of the Arabia-Eurasia collision zone, Gondwana Research 71, 194-209, https://doi.org/10.1016/j.gr.2019.01.018. 
978

979

980

981

982

983

984

985

986

987

988

989

990

991

992

993

994

995

996

997

998

Mercier, J.L., Carey-Gailhardis, E., and M. Sébrier (1991), Paleostress determinations from fault kinematics: application to the neotectonics of the Himalayan-Tibet and the central Andes, Philos. Trans. R. Soc., 337, 41-52.

Meyer, B., and K. Le Dortz (2007), Strike-slip kinematics in Central and Eastern Iran: estimating fault slip-rates averaged over the Holocene, Tectonics, 6, TC5009, doi:10.1029/2006TC002073, 2007.

Mohammadi Gharetapeh, A., Gholami, E., Khatib, M. M., Golchin, M. (2014), Development of structures in a shear stress regime in East Dasht-e Bayaz Fault Zone (East of Iran), Journal of Tethys, 2(2), $101-111$.

Molnar, P., and K.E. Dayem (2010), Major intracontinental strike-slip faults and contrasts in lithospheric strength, Geosphere, 6, 444-467.

Momeni, S.M., and M. Tatar (2018), Mainshocks/aftershocks study of the August 2012 earthquake doublet on Ahar-Varzaghan complex fault system (NW Iran), Phys. Earth Planet. Inter., 283, 67-81.

Mousavi, Z., Walpersdorf, A., Walker, R.T., Tavakoli, F., Pathier, E., Nankali, H., Nilfouroushan, F., and Y. Djamour (2013), Global Positioning System constraints on the active tectonics of NE Iran and the South Caspian region, Earth Planet. Sci. Lett., 377-378, 287-298, doi:10.1016/j.eps1.2013.07.007.

Nemcok, M., and R.J. Lisle (1995), A stress inversion procedure for polyphase fault slip data sets, J. Struct. Geol., 17, 1445-1453.

Nozaem, R., Mohajjel, M., Rossetti, F., Della Seta, M., Vignaroli, G., Yassaghi, A., Salvini, F., and M. Eliassi (2013), Post-Neogene right-lateral strike-slip tectonics at the north-western edge of the Lut Block (Kuh-e-Sarhangi Fault), Central Iran, Tectonophysics, 589, 220-233, doi:10.1016/j.tecto.2013.01.001. 
Rashid, H., Cifelli, F., Mattei M. (2015), Late folding-related magnetic foliation in the active Ferdows (northeastern Iran) thrust-fold system, Journal of Asian Earth Sciences 108, 48-57, http://dx.doi.org/10.1016/j.jseaes.2015.04.023.

Regard, V., Bellier, O., Thomas, J.-C., Bourlès, D., Bonnet, S., Abbassi, M.R., Braucher, R., Mercier, J., Shabanian, E., Soleymani, S., and K. Feghhi (2005), Cumulative right-lateral fault slip rate across the Zagros-Makran transfer zone: role of the Minab-Zendan fault system in accommodating ArabiaEurasia convergence in southeast Iran, Geophys. J. Int., 162, 177-203, doi:10.1111/j.1365246X.2005.02558.x.

Regard, V., Bellier, O., Braucher, R., Gasse, F., Bourlès, D., Mercier, J., Thomas, J.-C., Abbassi, M.R., Shabanian, E., and S. Soleymani (2006), ${ }^{10}$ Be dating of alluvial deposits from Southeastern Iran (the Hormoz Strait area), Palaeogeogr. Palaeoclimatol. Palaeoecol., 242, 36-53, doi:10.1016/j.palaeo.2006.05.012.

Reilinger, R., McClusky, S., Vernant, P., Lawrence, S., Ergintav, S., Cakmak, R., Ozener, H., Kadirov, F., Guliev, I., Stepanyan, R., Nadariya, M., Hahubia, G., Mahmoud, S., Sakr, K., ArRajehi, A., Paradissis, D., Al-Aydrus, A., Prilepin, M., Guseva, T., Evren, E., Dmitrotsa, A., Filikov, S.V., Gomez, F., Al-Ghazzi, R., and G. Karam (2006), GPS constraints on continental deformation in the Africa-Arabia-Eurasia continental collision zone and implications for the dynamics of plate interactions, J. Geophys. Res. 111, B05411, doi:10.1029/2005JB004051.

Ricou, L.E., Braud, J., and J.H. Bruhnn (1977), Le Zagros, Mem. H. Ser. Soc. Geol. Fr., 8, 33-52.

Ritz, J.-F., and A. Taboada (1993), Revolution stress ellipsoids in brittle tectonics resulting from an uncritical use of inverse methods, Bull. Soc. Geol. Fr., 164, 519-531. 
1020

1021

1022

1023

1024

1025

1026

1027

1028

1029

1030

1031

1032

1033

1034

1035

1036

1037

1038

1039

1040

1041

1042

Ritz, J.-F., Nazari, H., Ghassemi, A., Salamati, R., Shafei, A., Solaymani, S., and P.Vernant (2006), Active transtension inside Central Alborz: a new insight into northern Iran- southern Caspian geodynamics, Geology, 34, 477-480, doi:10.1130/ G22319.1.

Rossetti, F., Storti, F., and A.L. Laufer (2002), Brittle architecture of the Lanterman Fault and its impact on the final terrane assembly in north Victoria Land, Antarctica, Journal of the Geological Society, 159, 159-173.

Salvini, F., and F. Storti (1999), Cenozoic tectonic lineaments of the Terra Nova Bay region, Ross Embayment, Antarctica, Global Planetary Change, 23, 129-144.

Shabanian, E., Siame, L., Bellier, O., Benedetti, L., and M.R. Abbassi (2009a), Quaternary slip rates along the northeastern boundary of the Arabia-Eurasia collision zone (Kopeh Dagh Mountains, Northeast Iran), Geophys. J. Int., 178, 1055-1077, doi:10.1111/ j.1365-246X.2009.04183.x.

Shabanian, E., Bellier, O., Siame, L., Arnaud, N., Abbassi, M.R., and J.-J. Cochemé (2009b), New tectonic configuration in NE Iran: active strike-slip faulting between the Kopeh Dagh and Binalud mountains, Tectonics, 28, TC5002, doi:10.1029/2008TC002444.

Shabanian, E., Bellier, O., Abbassi, M.R., Siame, L., and Y. Farbod (2010), Plio-Quaternary stress states in NE Iran: Kopeh Dagh and Allah Dagh-Binalud mountain ranges, Tectonophysics, 480, 280-304, doi:10.1016/j.tecto.2009.10.022.

Shabanian, E., Acocella, V., Gioncada, A., Ghasemi, H. and O. Bellier (2012a), Structural control on volcanism in intraplate post collisional settings: Late Cenozoic to Quaternary examples of Iran and Eastern Turkey, Tectonics, 31(3), TC3013.

Shabanian, E., Bellier, O., Siame, L., Abbassi, M.R., Bourlès, D., Braucher, R., and Y. Farbod (2012b), The Binalud Mountains: A key piece for the geodynamic puzzle of NE Iran, Tectonics, 31, TC6003, doi:10.1029/2012TC003183. 
1043 Shan, J., Suen, H., and G. Lin (2003), Separation of polyphase fault/slip data: an objective function 1044 algorithm based on hard division, J. Struct. Geol., 25, 829-840.

1045 Tadayon, M., Rossetti, F., Zattin, M., Nozaem, R., Calzolari, G., Madanipour, S., and F. Salvini (2017), 1046 The post-Eocene evolution of the Doruneh Fault region (Central Iran): The intraplate response to the 1047 reorganization of the Arabia-Eurasia collision zone, Tectonics, 36, 3038-3064.

1048 Tadayon, M., Rossetti, F., Zattin, M., Calzolari, G., Nozaem, R., Salvini, F., Faccenna, C., and P. 1049 Khodabakhshi (2018), The long-term evolution of the Doruneh Fault region (Central Iran): A key to 1050 1051

Talebian, M., and J. Jackson (2004), A reappraisal of earthquake focal mechanisms and active shortening in the Zagros mountains of Iran, Geophys. J. Int., 156, 506-526. Nilforoushan, F., and N. Cotte (2008), Distribution of the right-lateral strike-slip motion from the Main Recent Fault to the Kazerun Fault System (Zagros, Iran): Evidence from present-day GPS velocities, Earth Planet. Sci. Lett, 275, 342-347, doi:10.1016/j.eps1.2008.08.030.

1061 Tchalenko, J.S., and N.N. Ambraseys (1970), Structural analysis of the Dasht-e Bayaz (Iran) earthquake 1062 fractures, Geol. Soc. Am. Bull., 81, 41-60.

1063 Tchalenko, J.S., Braud, J., and M. Berberian (1974), Discovery of three earthquake faults in Iran, Nature, 1064 248, 661-663. 
1065 Tchalenko, J.S., and M. Berberian (1975), Dasht-e-Bayaz fault, Iran: earthquake and earlier related 1066 structures in bed-rock, Geol. Soc. Am. Bull., 86, 703-709.

1067 Tranos, M.D., (2015), TR method (TRM): a separation and stress inversion method for heterogeneous 1068 fault-slip data driven by Andersonian extensional and compressional stress regimes, J. Struct. Geol., 1069 79, 57-74, doi:10.1016/j.jsg.2015.07.006.

1070 Tranos, M.D., (2018), The use of Stress Tensor Discriminator Faults in separating heterogeneous fault1071 slip data with best-fit stress inversion methods, J. Struct. Geol., 107, 153-162.

1072 Vernant, P., Nilforoushan, F., Hatzfeld, D., Abbassi, M.R., Vigny, C., Masson, F., Nankali, 1073 H., Martinod, J., Ashtiani, A., Bayer, R., Tavakoli, F., and J. Chery (2004), Present-day crustal 1074 deformation and plate kinematics in the Middle East constrained by GPS measurements in Iran and 1075 northern Oman, Geophys. J. Int., 157, 381-398.

1076 Walker, R.T., Jackson, J., and C. Baker (2003), Thrust faulting in eastern Iran: source parameters and 1077 surface deformation of the 1978 Tabas and 1968 Ferdows earthquake sequences, Geophys. J. Int., $1078 \quad 152,749-765$.

1079 Walker, R.T., and J. Jackson (2004), Active tectonics and late Cenozoic strain distribution in central and 1080 eastern Iran, Tectonics, 23, TC5010, doi:10.1029/2003TC001529.

1081 Walker, R.T., Jackson J., and C. Baker (2004), Active faulting and seismicity of the Dasht-e-Bayaz 1082 region, eastern Iran, Geophys. J. Int., 157, 265-282.

1083 Walker, R.T., Bergman, E.A., Szeliga, W., and E.J. Fielding (2011), Insights into the 1968-1997 Dasht-e1084 Bayaz and Zirkuh earthquake sequences, eastern Iran, from calibrated relocations, InSAR and high1085 resolution satellite imagery, Geophys. J. Int., 187, 1577-1603, doi:10.1111/j.1365$1086 \quad$ 246X.2011.05213.x. 
1087 Wallace R.E., (1951), Geometry of shearing stress and relation to faulting, J. Geol., 59, 118-130.

1088 Walpersdorf, A., Hatzfeld, D., Nankali, H., Tavakoli, F., Nilforoushan, F., Tatar, M., Vernant, P., Chéry, 1089 J., and F. Masson (2006), Difference in the GPS deformation pattern of North and Central Zagros 1090 (Iran), Geophys. J. Int., 167, 1077-1088.

1091 Walpersdorf, A., Manighetti, I., Mousavi, Z., Tavakoli, F., Vergnolle, M., Jadidi, A., Hatzfeld, D., 1092 Aghamohammadi, A., Bigot, A., Djamour, Y., Nankali, H., and M. Sedighi (2014), Present-day 1093 kinematics and fault slip rates in eastern Iran, derived from 11 years of GPS data, J. Geophys. Res., $1094 \quad 119,1359-1383$.

1095 Yassaghi, A., and S. Madanipour (2008), Influence of a transverse basement fault on along-strike 1096 variations in the geometry of an inverted normal fault: case study of the 1097 Mosha Fault, Central Alborz Range, Iran, J. Struct. Geol., 30, 1507-1519.

1098 Zanchi, A., Berra, F., Mattei, M., Ghassemi, M.R., and J. Sabouri (2006), Inversion tectonics in central 1099 Alborz, Iran, J. Struct. Geol., 8, 2023-2037.

1100 Zoback, M.L., (1989), State of stress and modern deformation of the basin and range province, J. $1101 \quad$ Geophys. Res., 94, 7105-7128. 


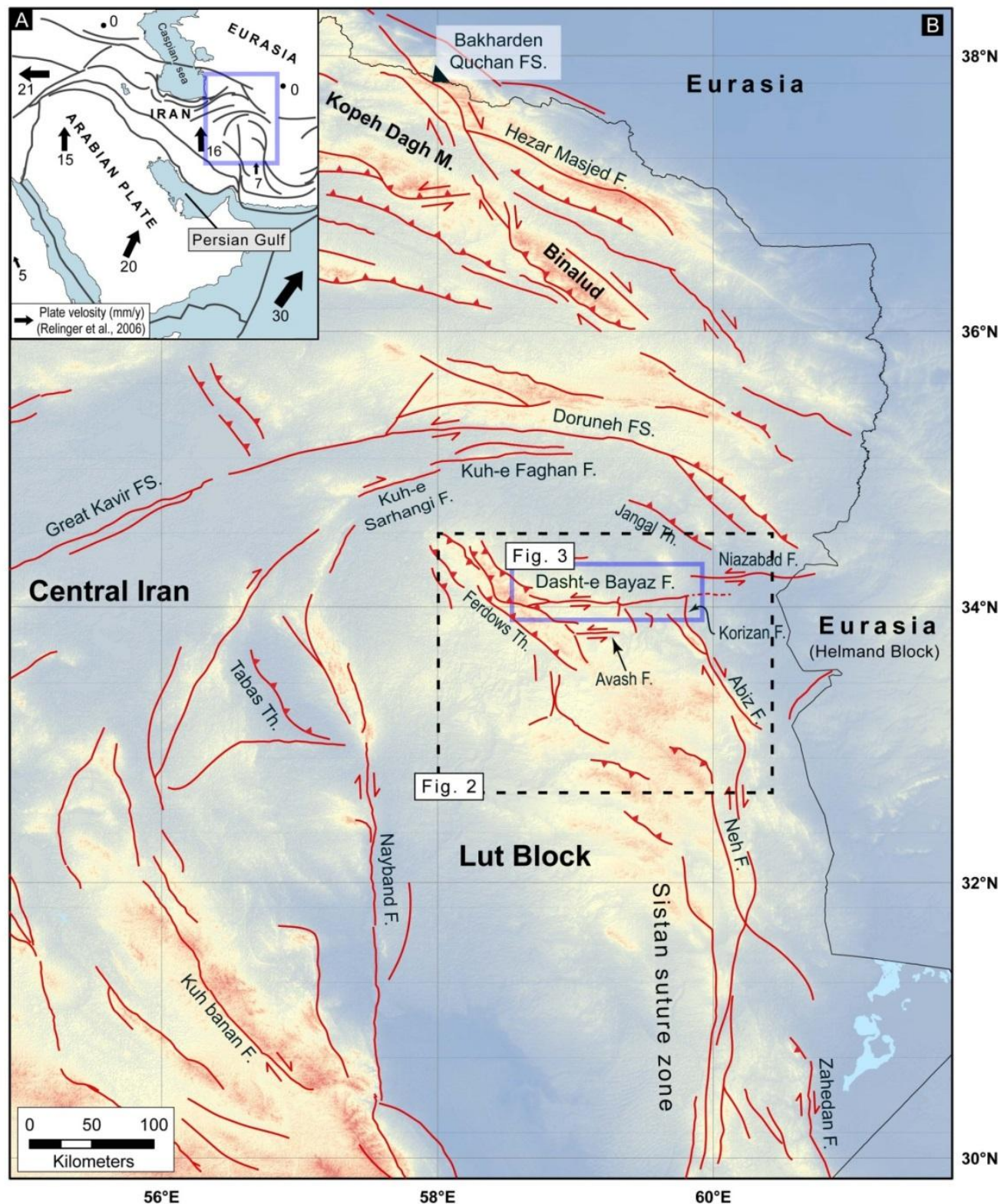

1104 Figure 1. General tectonic map of the east and northeastern Iran. (A) The location of the study area 1105 (blue rectangle) in the Arabia-Eurasia collision framework (after Shabanian et al., 2010). Grey arrows 1106 and associated numbers represent Arabia-Eurasia plate velocities (mm/yr) after Reilinger et al. (2006). 1107 Solid lines are boundaries of plates or major blocks. (B) GTOPO30 topographic image showing the 1108 regional tectonic setting and the major active faults (red lines) in E and NE Iran. The study area of Dasht1109 e Bayaz is marked by the black dashed rectangle. Reverse/thrust faults are marked by small triangles 1110 pointing to the fault hanging wall. The fault map is based on Hessami et al. (2003), Walker and Jackson 1111 (2004), Shabanian et al. (2010), Farbod et al. (2011), Nozaem et al. (2013), Calzolari et al. (2015) and this 1112 study. 


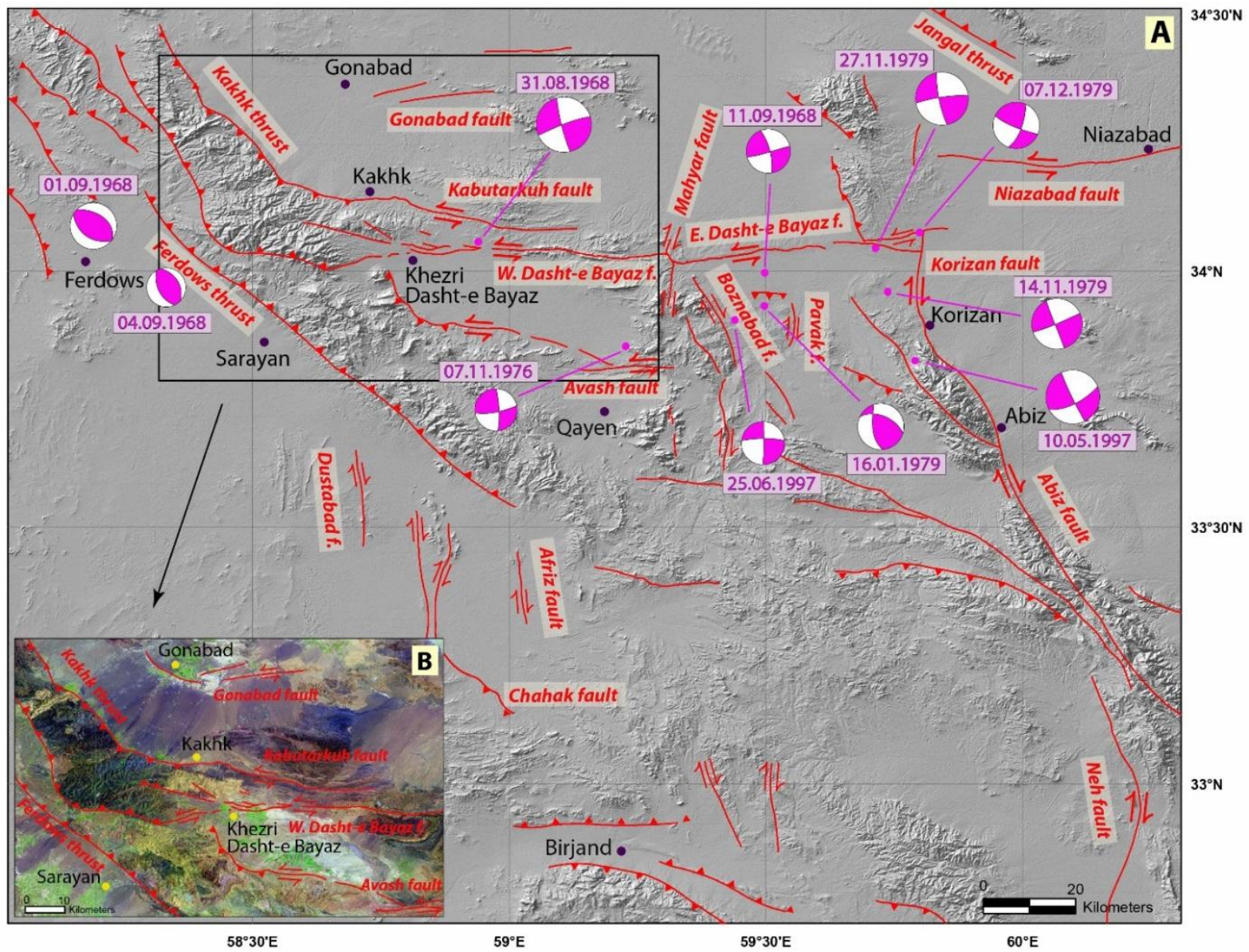

Figure 2. Map of the major active faults around the Dasht-e Bayaz area. (A) Major fault zones and

1115 their structural interactions in the area of interest. Focal mechanism solutions belong to the major 1116 earthquakes of the study area (redrafted from waveform modeling of Walker et al., 2004 and 2011). (B)

1117 LANDSAT ETM satellite overview (RGB, 541) of the area emphasizing the western termination of the 1118 left-lateral Dasht-e Bayaz, Kabutarkuh and Avash faults. 

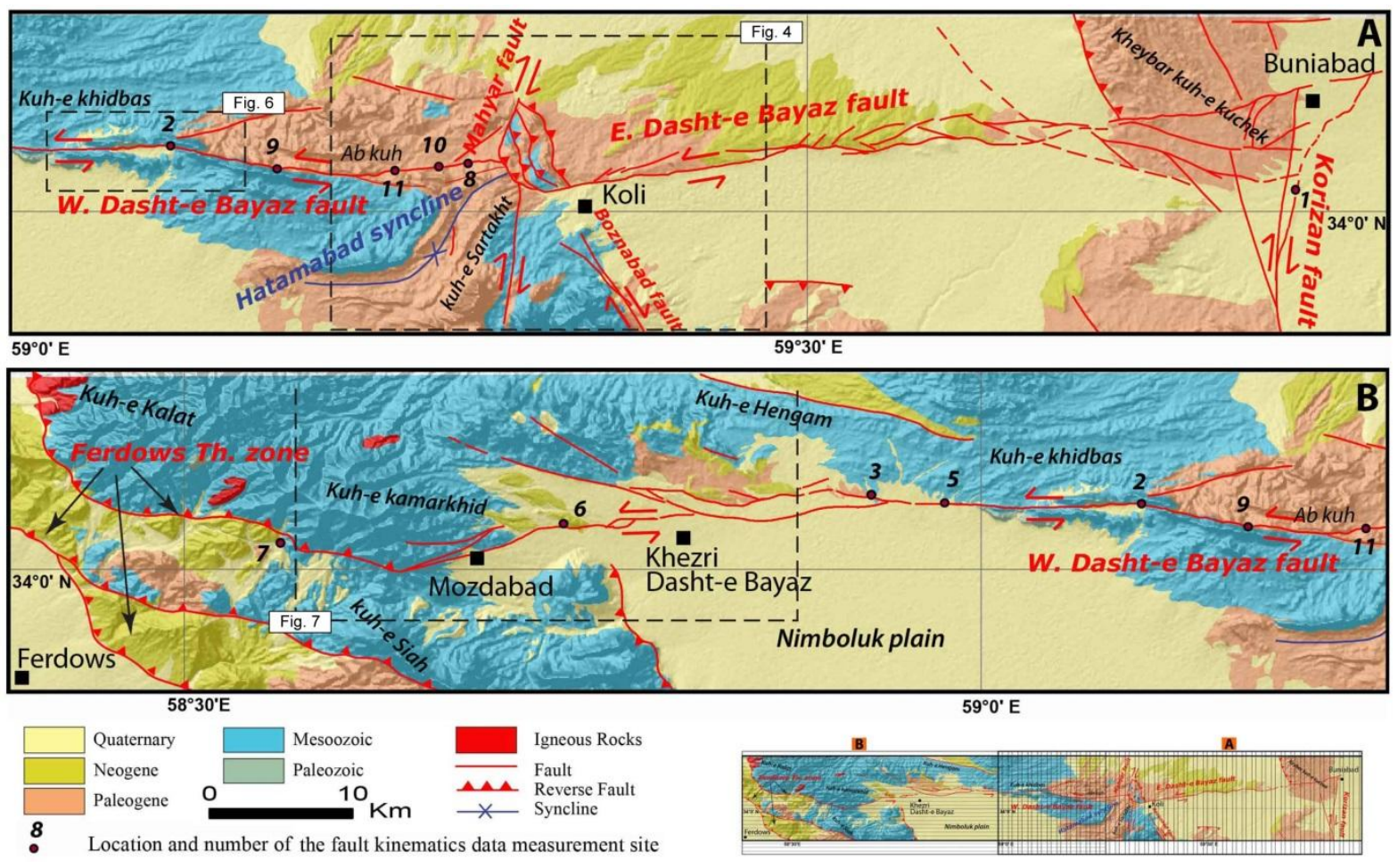

1121 Figure 3. Simplified geological map of the Dasht-e Bayaz area based on published geological maps 1122 of the area (Alavi Naini and Behruzi, 1983; Fauvelet and Eftekhar Nezhad, 1991). Fault traces were 1123 extracted from satellite images complemented by field observations; we used Tchalenko and Berberian 1124 (1975) maps for the co-seismic ruptures in the northern Nimboluk plain, which currently is under 1125 cultivation. 


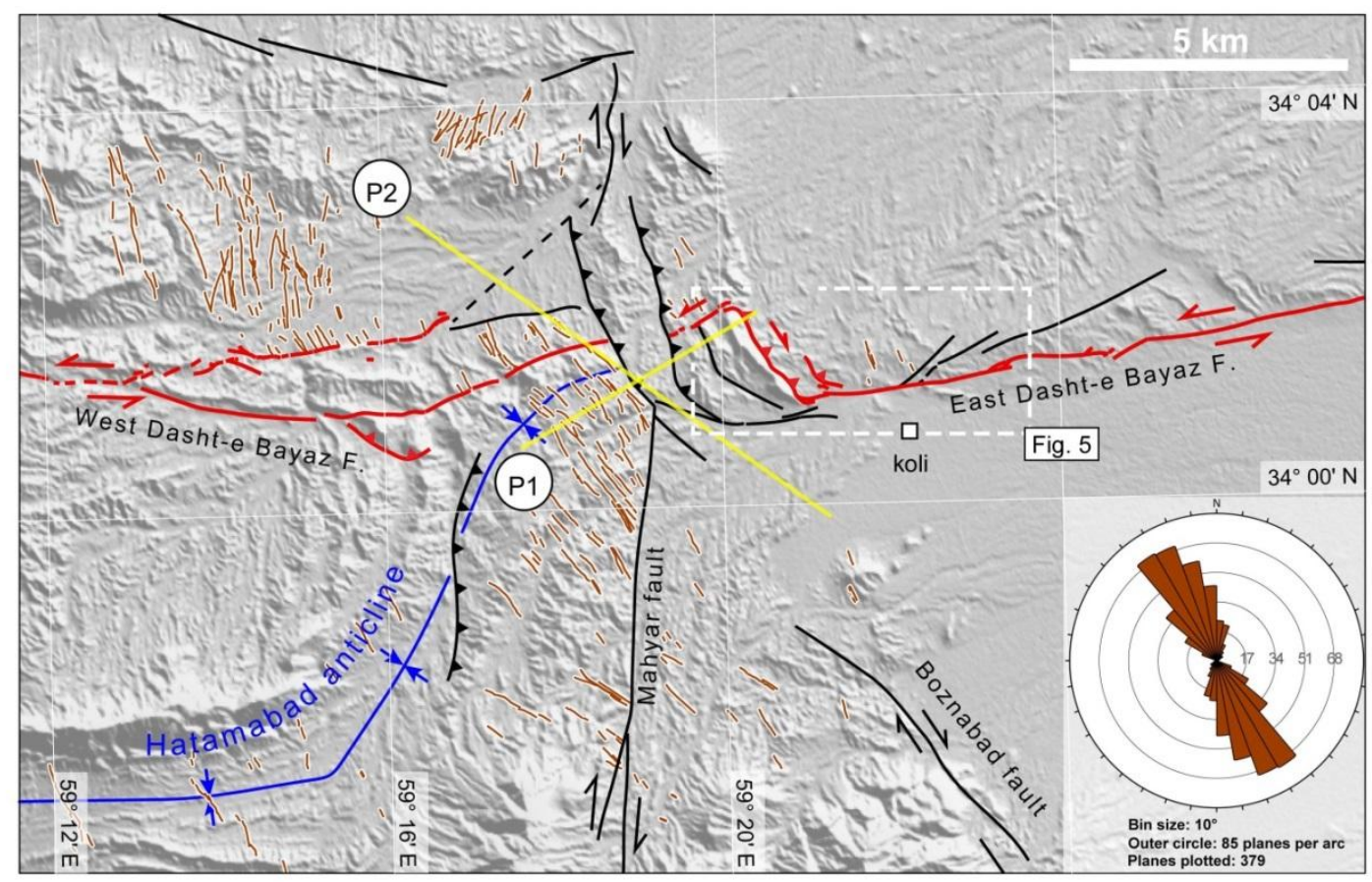

(P1)

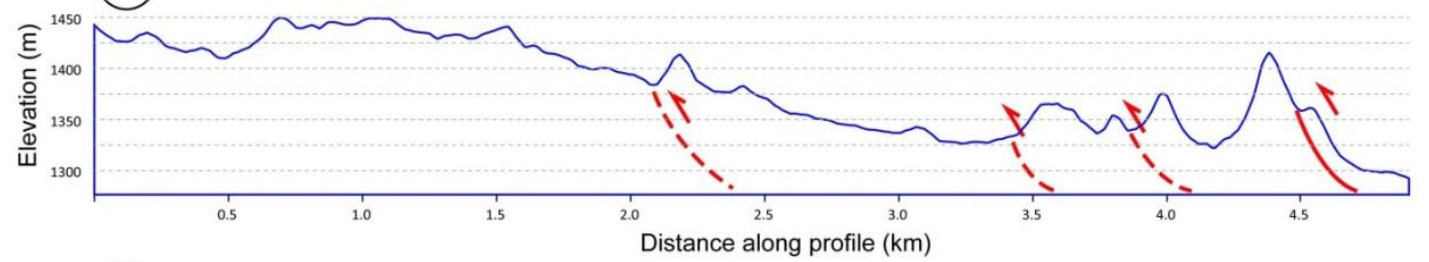

(P2)

From Pos: $59.293^{\circ} \mathrm{E}, \mathrm{N} 34.010^{\circ} \mathrm{N}$ to Pos: $59.340^{\circ} \mathrm{E}, 34.031^{\circ} \mathrm{N}$

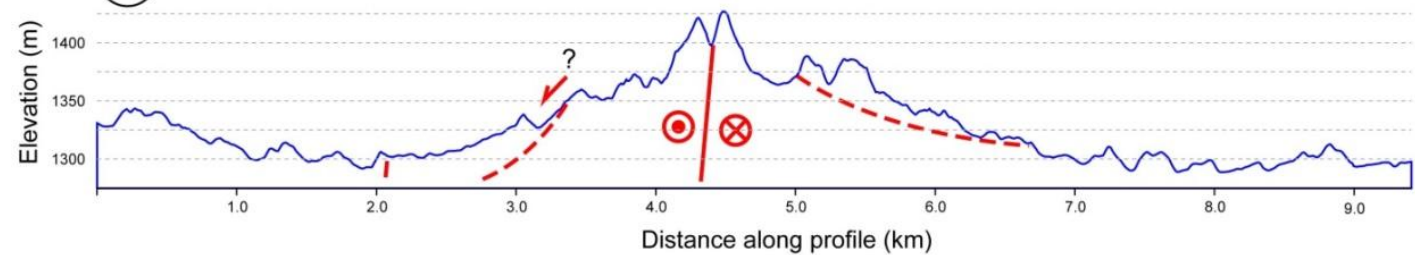

From Pos: $59.272^{\circ} \mathrm{E}, 34.048^{\circ} \mathrm{N}$ to Pos: $59.354^{\circ} \mathrm{E}, 33.998^{\circ} \mathrm{N}$

1127 Figure 4. Morpho-structural map of the central intersection zone along the Dasht-e Bayaz fault. (A)

1128 Detailed fault map of the interaction zone of the Mahyar and the Dasht-e Bayaz faults. Solid black line is 1129 geological fault; inferred fault is shown by dashed black line. Red solid line is the coseismic rupture of 1130 the Dasht-e Bayaz 1968 (west of the Mahyar fault) and 1979 (east of the Mahyar fault) earthquakes. The 1131 N-S dextral and E-W sinistral fault zones displaced each other in the sense of their movement of about $11321.5 \mathrm{~km}$; see Figure 17 for more details on the structural configuration of this zone. The lower right rose 1133 diagram (rosette) indicates the frequency of orientations of post-folding dikes (cut by strike-slip faults) 1134 concentrated around the intersection zone; note that the overall orientation of $\mathrm{N} 330 \pm 10^{\circ} \mathrm{E}$ does not 1135 significantly vary along the strike-slip faults. Two topographic profiles across the contractional (P1) and 1136 extensional (P2) quadrants are shown. 

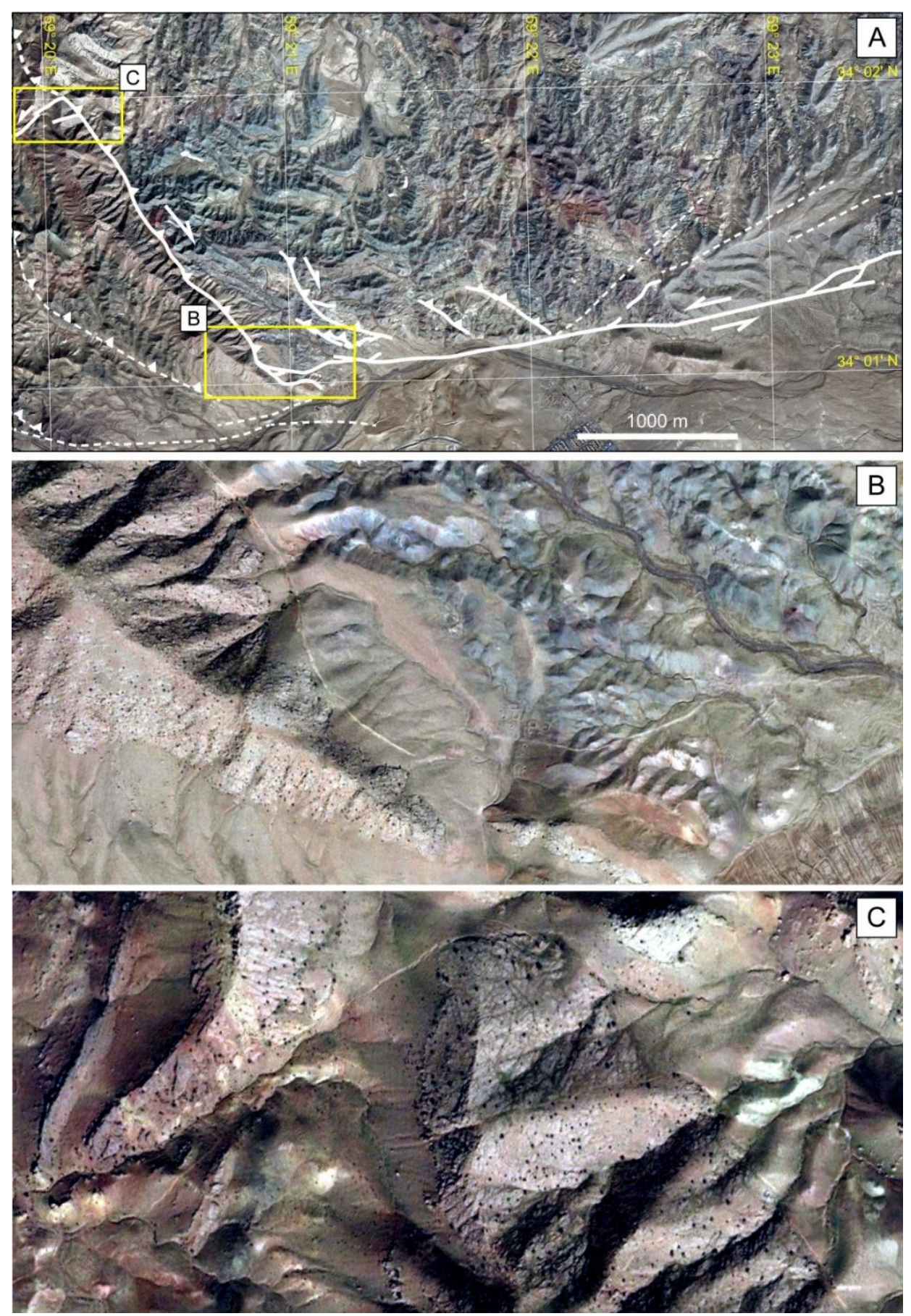

1138 Figure 5. Bing Map image (SAS.Planet $\odot$ 2015-2017) centered on the western termination of the

1139 East Dasht-e Bayaz fault. See Figure 3 for location. (A) Detailed fault map of the area. Solid white lines

1140 are coseismic rupture traces and dashed white lines are geological faults not reactivated during the 1979

1141 Dasht-e Bayaz earthquake. (B) Close-up view of the sinistral rupture that terminates in a NE-dipping

1142 reverse segment. (C) Close-up view of the northern end of the reverse fault segment due to intersection

1143 with a SW-trending sinistral segment. 

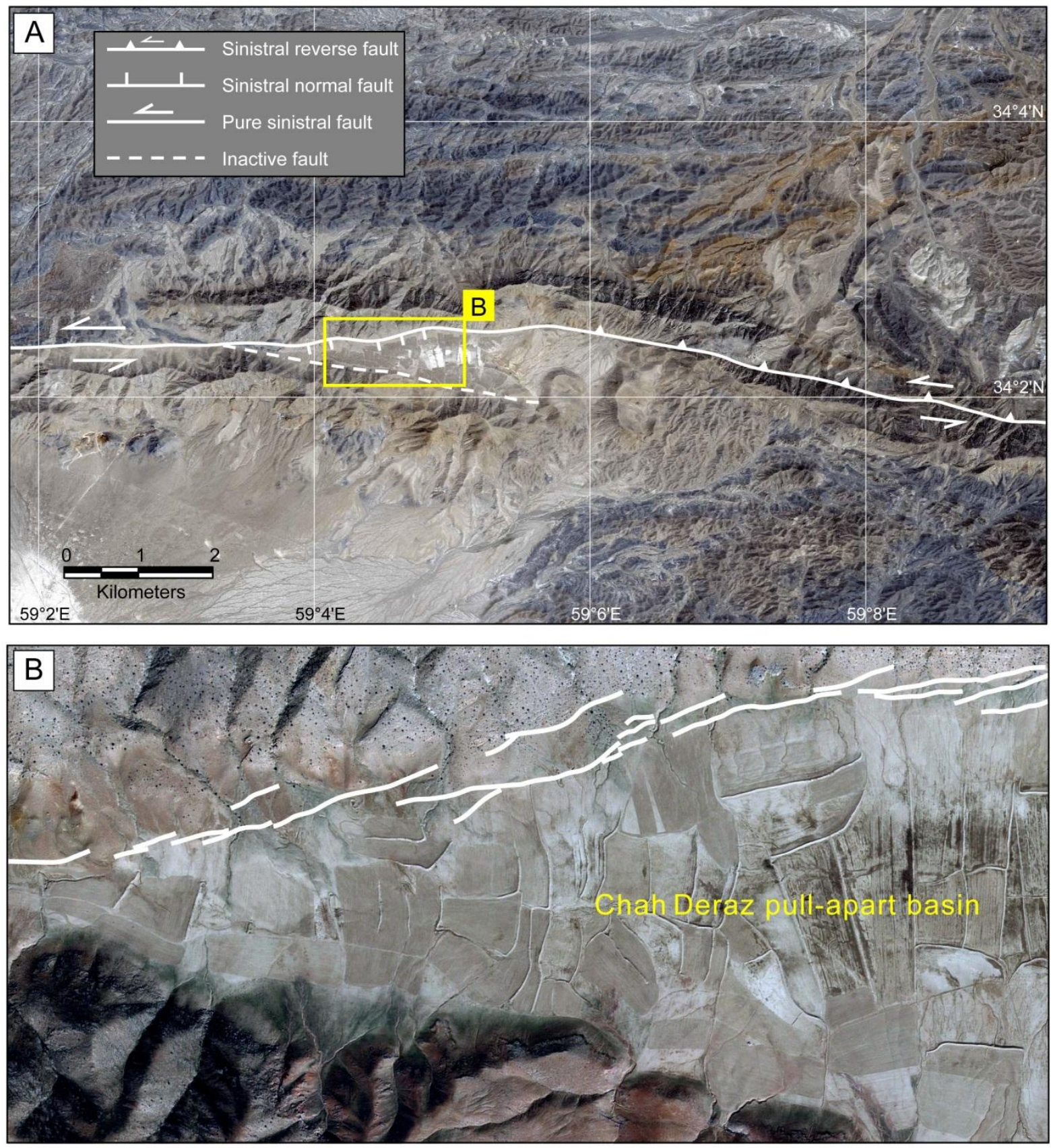

1145 Figure 6. SPOT image of the Chah Deraz pull-apart basin along the west Dasht-e Bayaz fault. (A) 1146 the active trace of the fault passes at the northern margin of the basin, while the southern one is inactive. 1147 (B) close-up view of the coseismic rupture (1968 Dasht-e Bayaz earthquke) at the northen margin of the 1148 basin. 

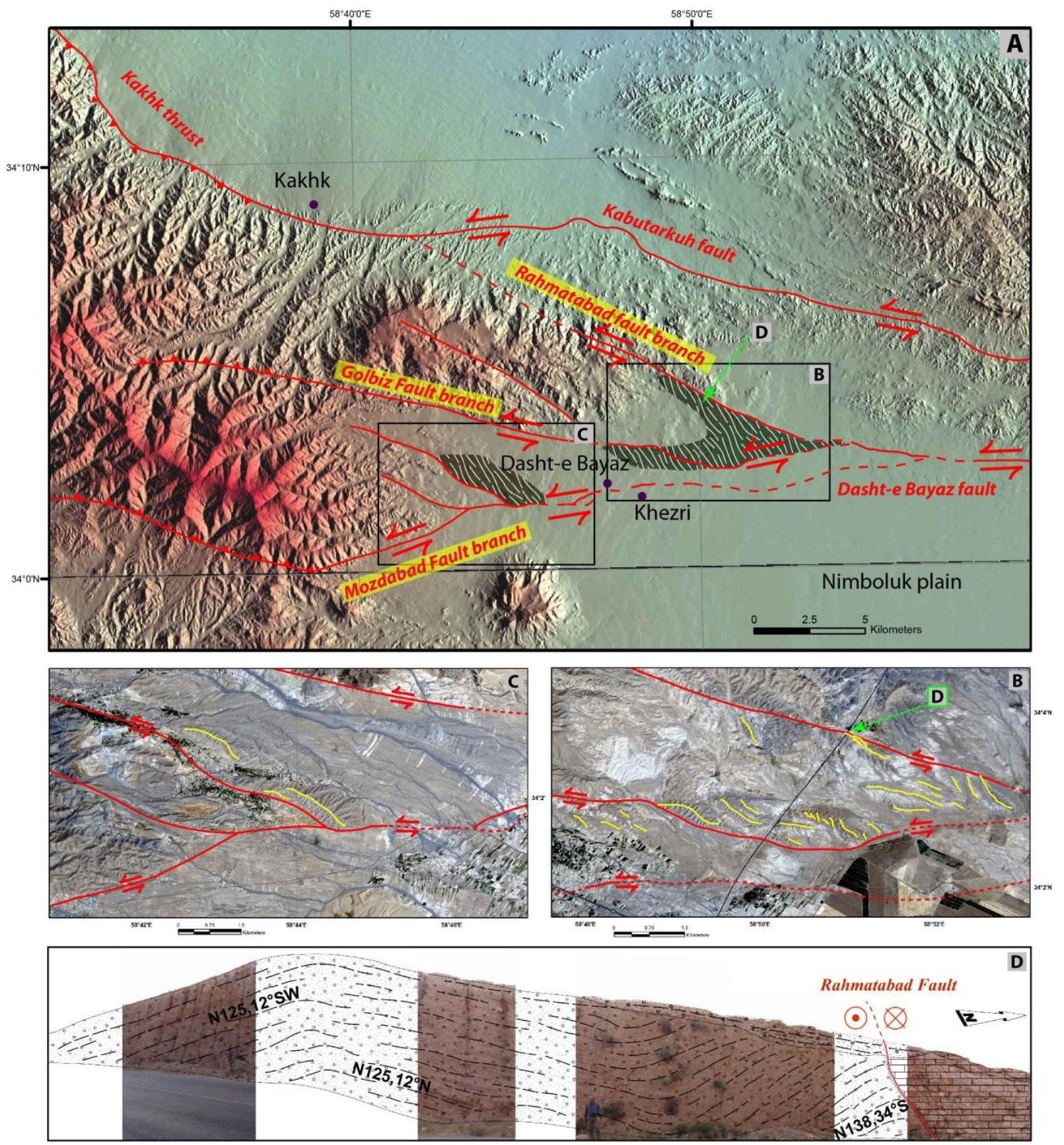

$1150 \quad$ Figure 7. Tectonic features of the western portion of the west Dasht-e Bayz fault. (A) Shaded relief

1151 image of the northern Nimboluk plain and structural map of this area including different fault branches of

1152 the Dasht-e Bayaz fault. The hatched polygon shows areas involved in en-echelon folding and pressure

1153 ridges. (B) and (C) SPOT image of the Northern Nimboluk plain. Fold axes shown as yellow lines. (D)

1154 West looking photographs and reconstructed section across the Rahmatabad fault branch and associated

1155 folding of Plio-Quaternary deposits in the footwall. 

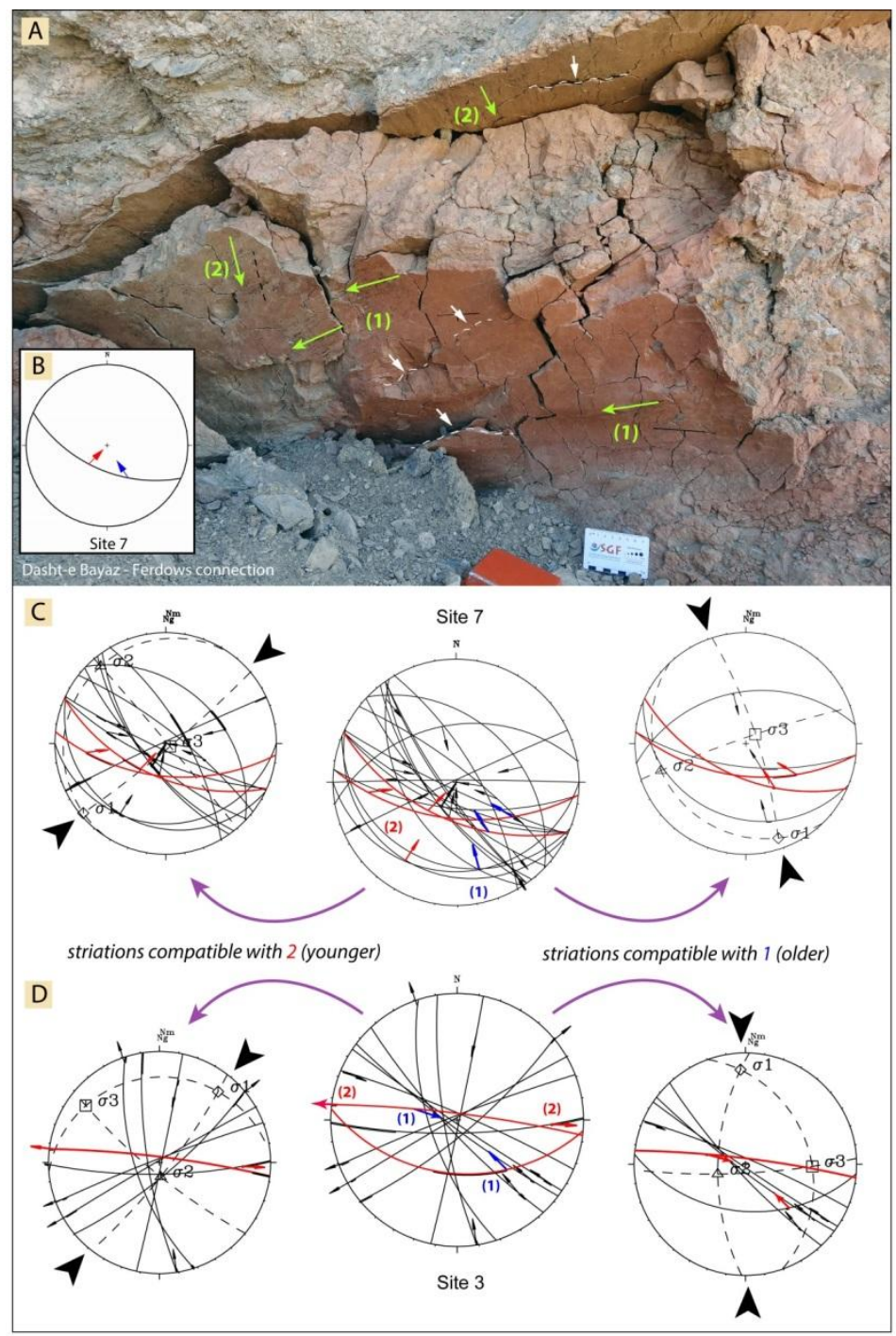

$1157 \quad$ Figure 8. Distinct fault slips related to the modern and intermediate states of stress and a summary of 1158 data separation strategy applied in this study. (A) SE looking field photograph a fault plane (site 7) that 1159 includes two generations of striations and (B) a stereoplot of these striations. (1) and (2) refer to older and 1160 younger relative chronologies, respectively, of the striations on the fault plane in the Neogene mudstone.

1161 This site is along the western end of the Dasht-e Bayaz fault where it merges the Ferdows reverse fault 1162 zone. (C) The schmidt lower hemisphere stereographic projection of the fault slip data measured in site 7. 1163 (D) The lower hemisphere stereographic projection of the fault slip data measured in site 3. The middle 1164 diagram is non-separated data set including all fault slip data. (1) and (2) refer to the older and younger 1165 relative chronology of the striations. The stereograms (1) and (2) indicate relative chronology of two 1166 distinct sets of data. The relative chronology of striations is according to cross-cutting relationships 1167 observed on fault planes (colored as red). This strategy is applied to other sites for separation of fault slip 1168 data into homogenous data sets. 

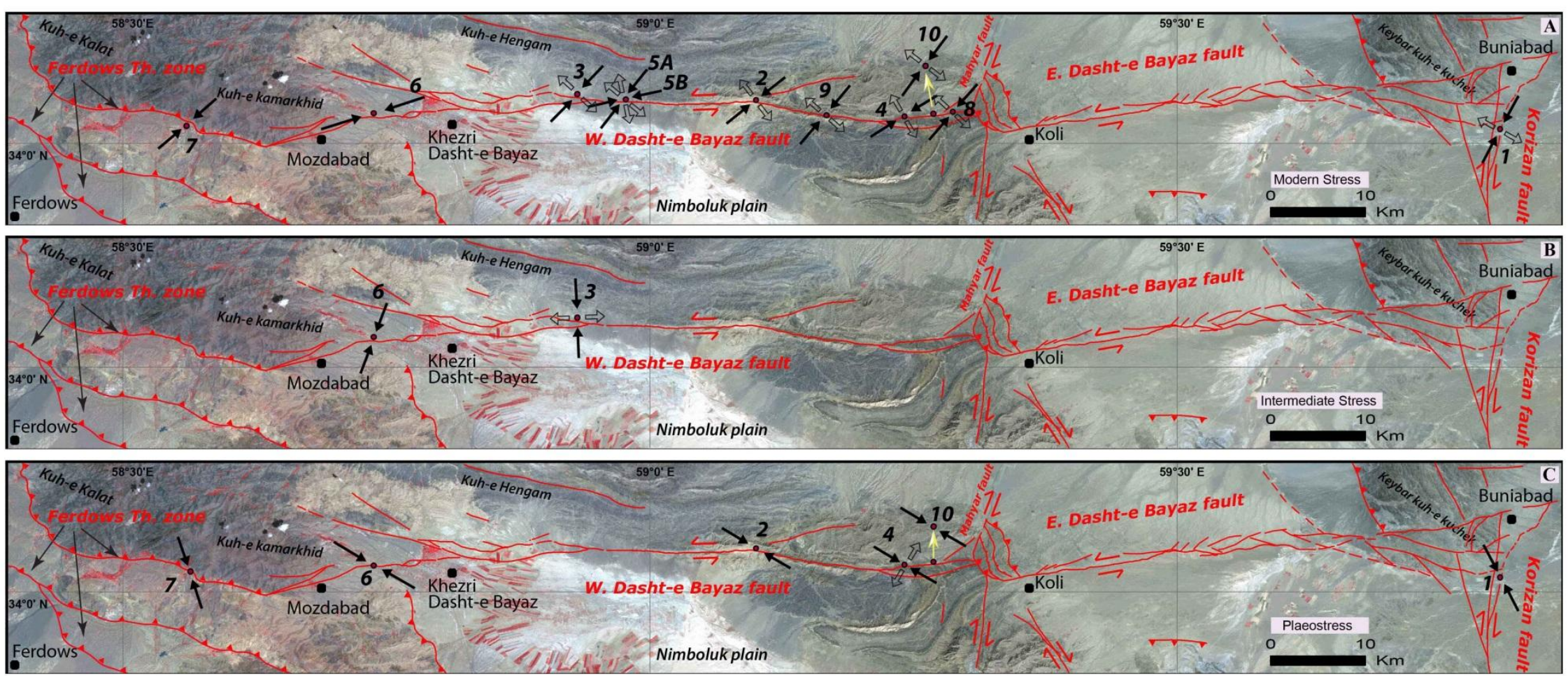

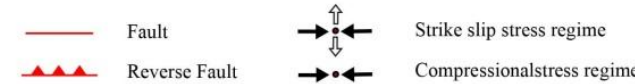

Figure 9. Reconstruction of the Plio-Quaternary stress fields in the Dasht-e Bayaz area, the base is ASTER image (RGB, 321). Direction of

1171 Maximum horizontal stress axis $(\sigma 1)$ for different stress fields showing dominant stress regimes including strike-slip, compressional and

1172 extensional deducted from inversions of fault kinematics data in each sites (see Table 2). (A) Modern state of stress (B) Intermediate state of

1173 stress (C) Paleostress state of stress. 


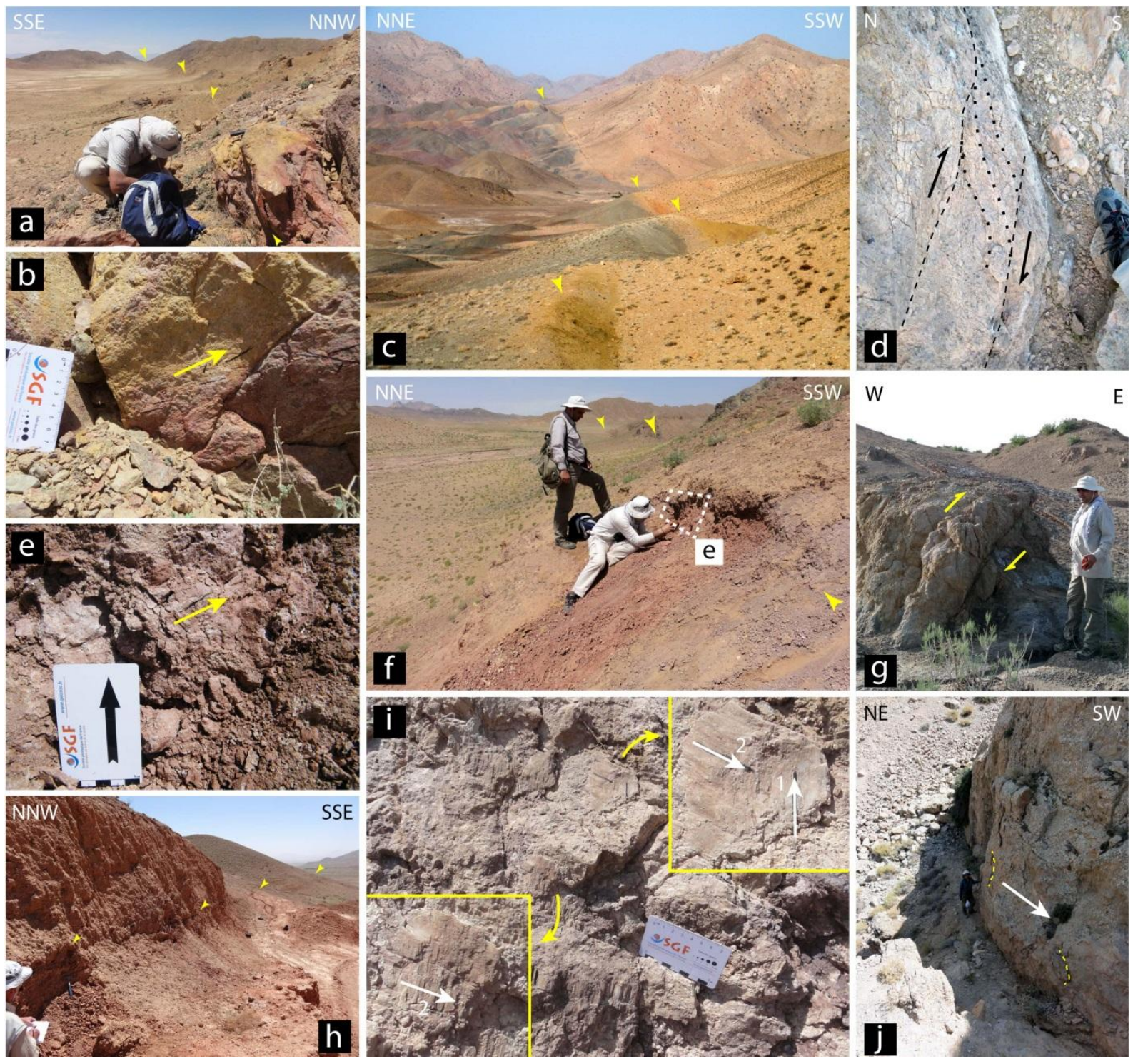

1175 Figure 10. Field photographs of some of sites we have inspected for the measurement of fault 1176 slip data along the Dasht-e Bayaz fault. (a) Site 2 at the northern margin of the Chah Deraz pull-apart 1177 basin. (b) A northwards view of the fault plane and the associated sinistral striation in site 2. (c) 1178 general view of the Dashte- Bayaz earthquake rupture to the west of the intersection zone. (d) 1179 structural evidence of an ancient dextral faulting along the main trace of the Dasht-e Bayaz fault in the 1180 Chah Deraz pull-apart basin. (e) and (f) fault plane and striation of the fault measured along the 1181 coseismic rupture. (g) An outcrop of the northern continuation of the Korizan fault in site 1. (h) The 1182 reverse-sinistral fault trace in Neogene deposits in site 6. (i) a fault plane with two distinct generation 1183 of striations in site 10. (j) a metric scale sinistral fault plane along the main fault zone in site 9 . 

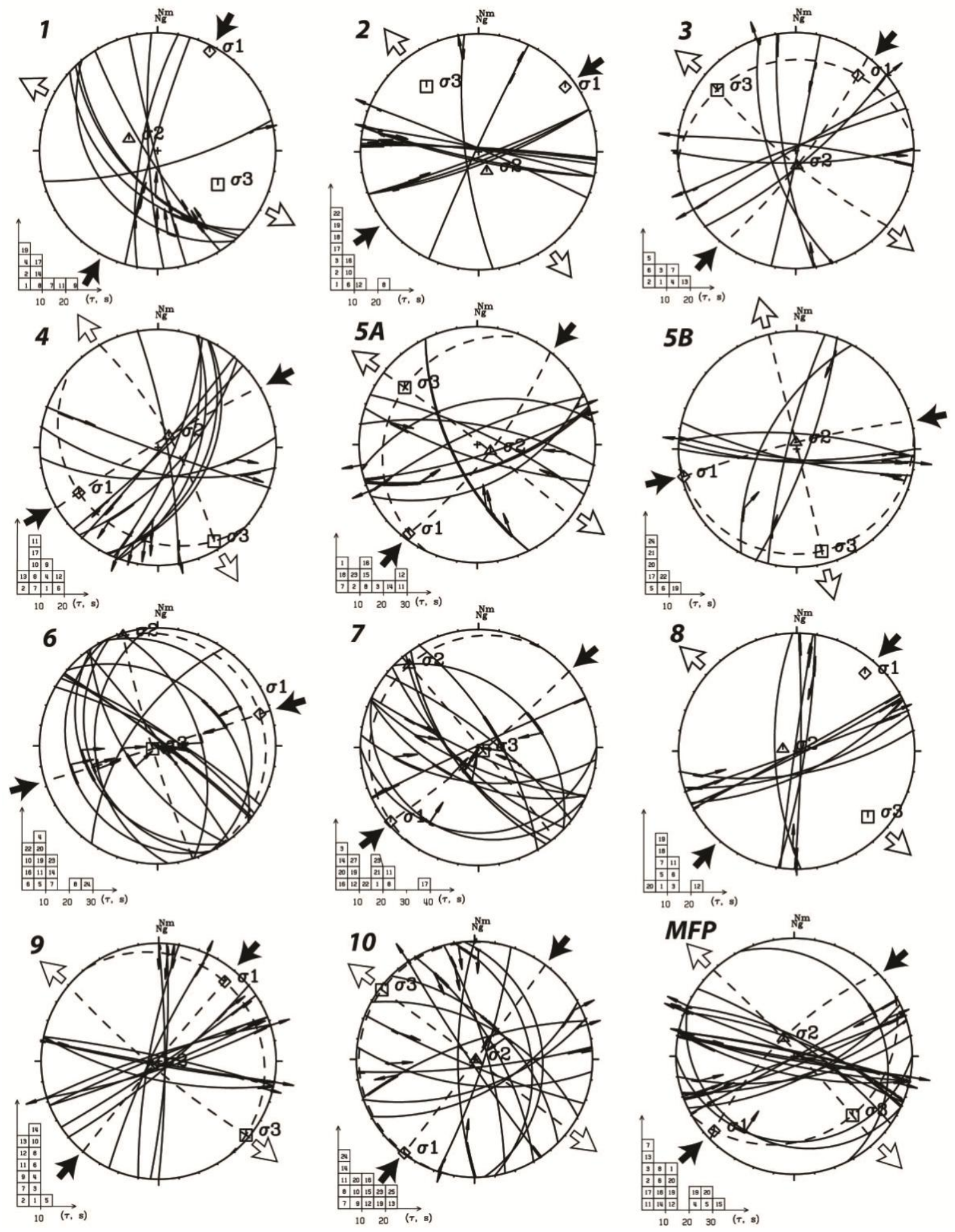

Figure 11. Lower hemisphere stereograms of fault slip data with inversion results of the modern state of stress presented in Table 1. Fault planes and measured slip vectors (arrows on fault

1187 planes) are plotted. Large arrows outside stereograms represent the direction of minimum ( $\sigma_{3}$, 1188 divergent, white arrows) and maximum $\left(\sigma_{1}\right)$ horizontal stress axes. Histograms show 1189 distribution of deviation angles between the measured and calculated slip vectors (e.g., 1190 Bellier and Zoback, 1995). Numbers on top left of stereograms refer to site marked in Figure 9 as 1191 well as in Table 1. MFP refers to result of inversion of major fault plane data. 

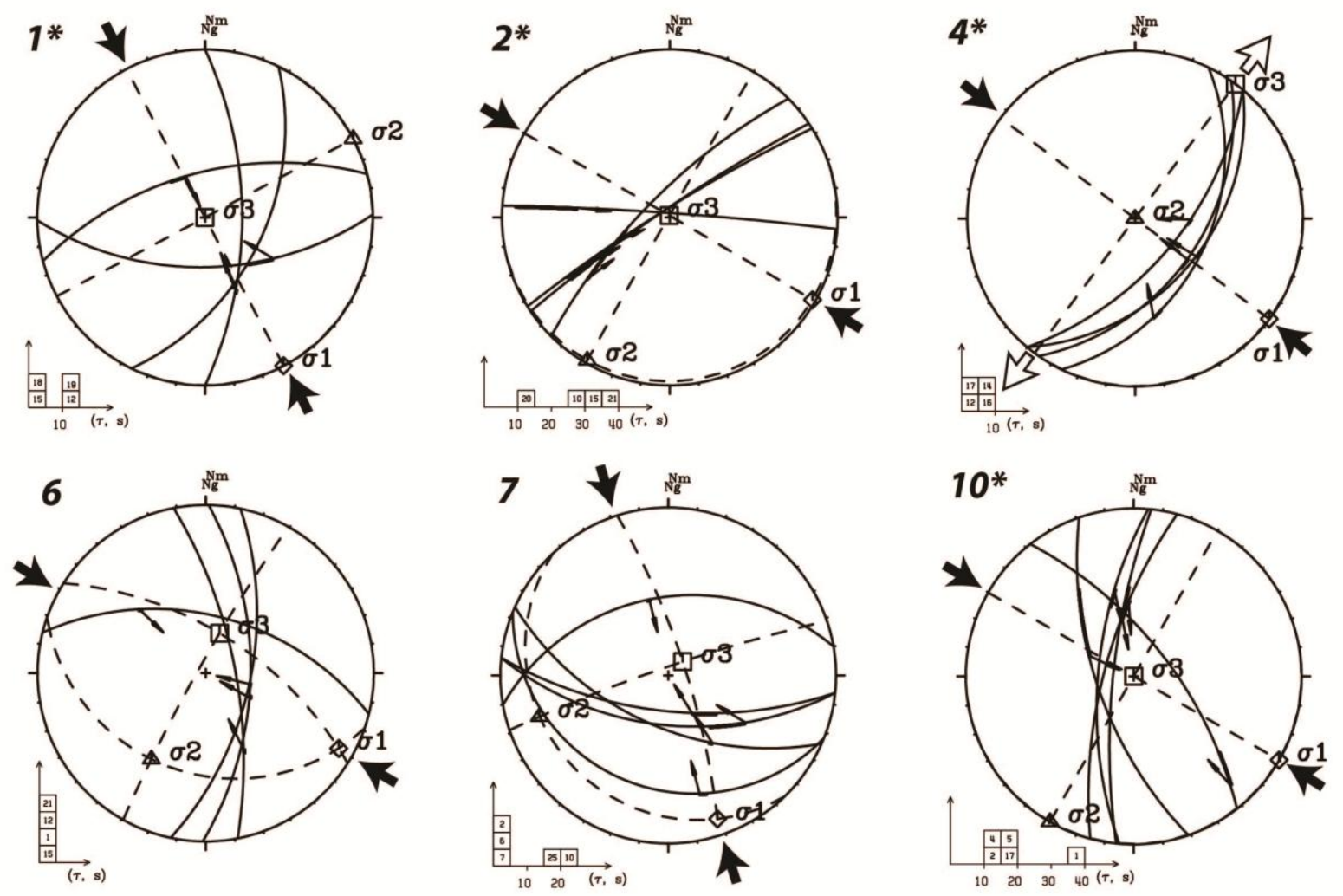

Figure 12. Lower hemisphere stereograms of fault slip data with inversion results of the 1194 paleostress state presented in Table 1. Numbers on top left of stereograms refer to site marked in 1195 Figure 9 as well as in Table 1. The stereograms indicated by asterisk are the "fixed" solutions (Bellier 1196 and Zoback, 1995) for fault data populations comprised of less than four well-distributed fault 1197 directions. See the caption of Figure 11 for stereoplot descriptions. 

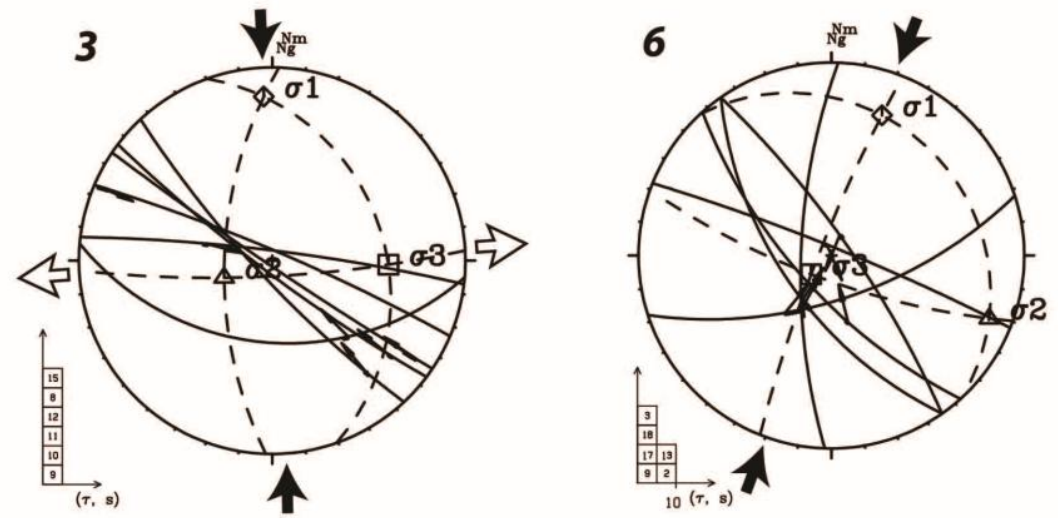

1200 Figure 13. Lower hemisphere stereograms of fault slip data with inversion results of the 1201 intermediate state of stress presented in Table 1. Numbers on top left of stereograms refer to site 1202 marked in Figure 9 as well as in Table 1. See the caption of Figure 11 for stereoplot descriptions. 


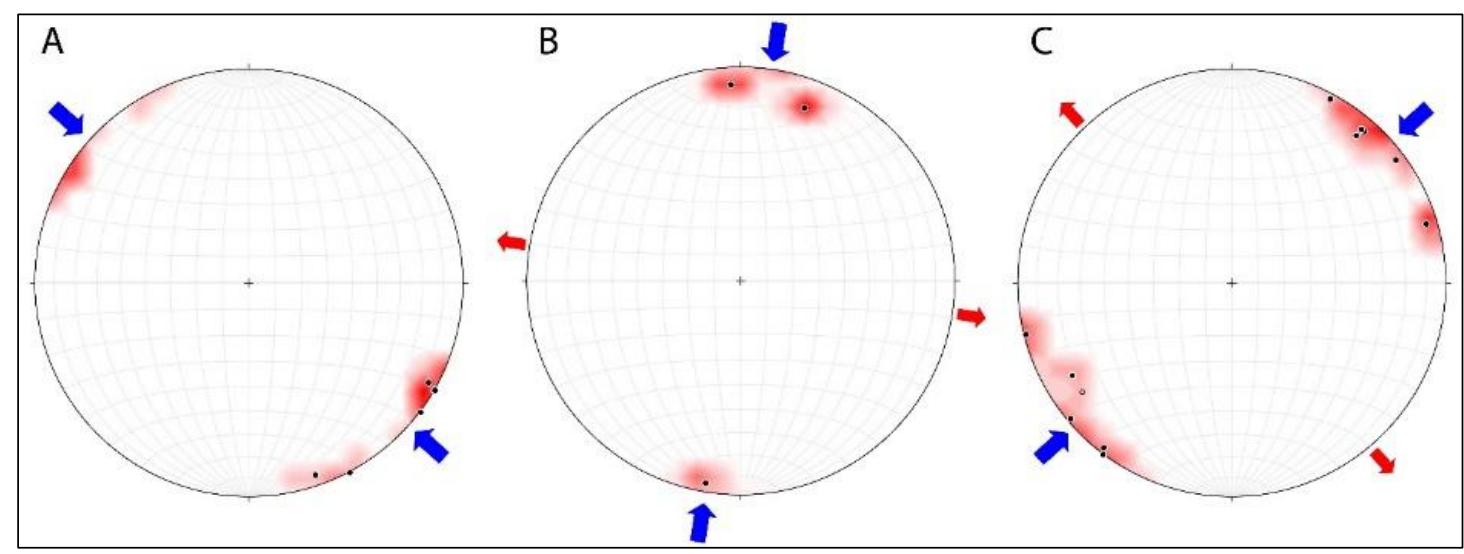

1205 Figure 14. Lower hemisphere stereograms showing statistical analysis of the preferred direction

1206 of the maximum horizontal stress axis $\left(\sigma_{1}\right)$ corresponding to (A) paleostress state $\left(\mathrm{N} 135 \pm 15^{\circ} \mathrm{E}\right)$, (B)

1207 intermediate state of stress $\left(\mathrm{N} 009 \pm 10^{\circ} \mathrm{E}\right)$ and $(\mathrm{C})$ modern state of stress $\left(\mathrm{N} 45 \pm 05^{\circ} \mathrm{E}\right)$; all calculated in

1208 PBT axes method (Marrett and Allmendinger, 1990; Allmendinger et al., 2013). Blue and red arrows

1209 indicate the mean direction of $\sigma_{1}$ and $\sigma_{3}$, respectively.

1210 


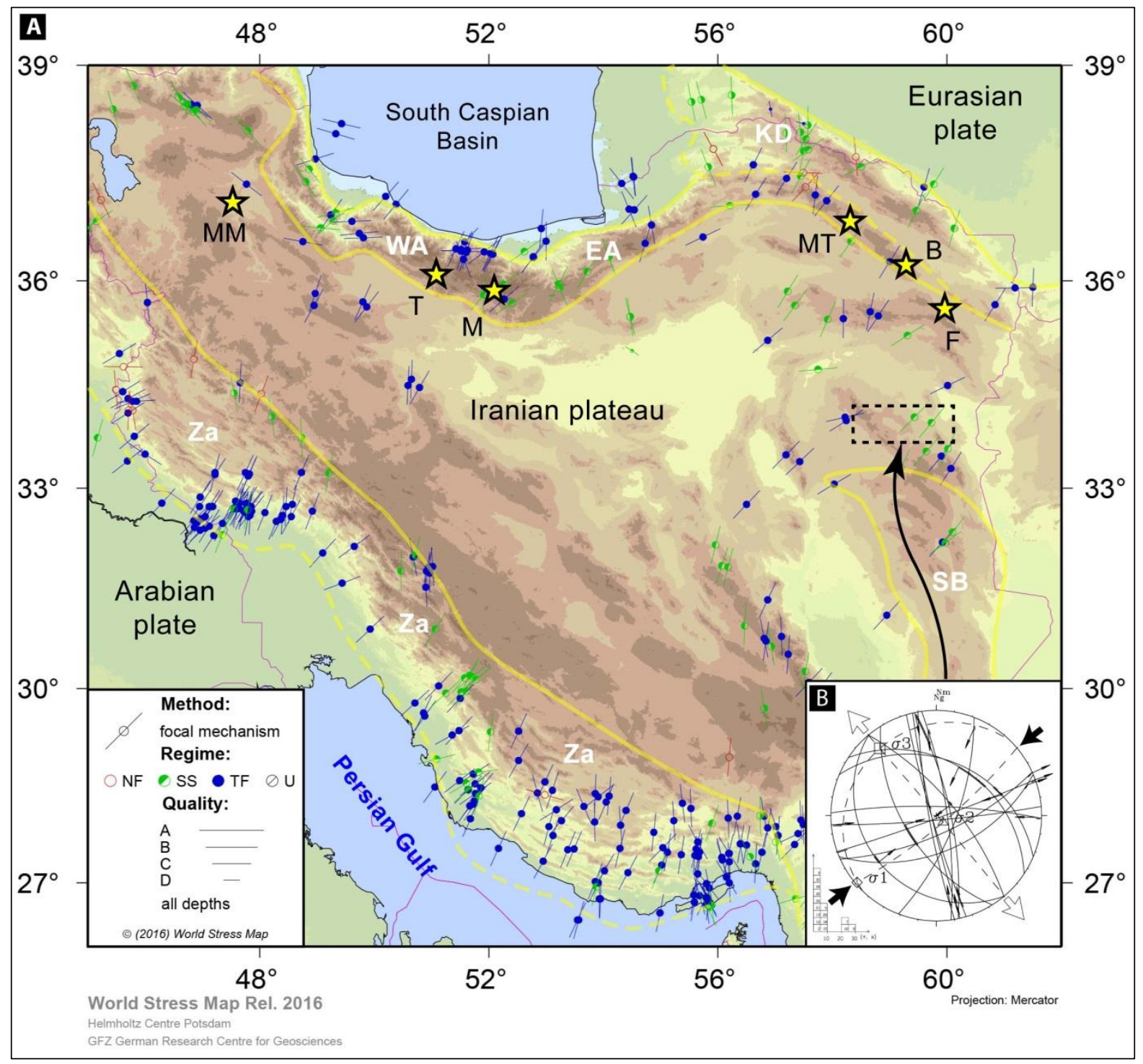

1212 Figure 15. Stress map of the Iranian plateau and surrounding mountain belts. (A) $\mathrm{S}_{\mathrm{H}} \max$ 1213 orientations deriving from some of earthquake focal mechanisms in the Iranian plateau created by 1214 online stress map creator: http://www.world-stress-map.org/casmo/ (see Heidbach et al., 2016 and 1215 references therein). Abbreviation is: TF, thrust faulting; SS, strike-slip; NF, normal faulting; U, 1216 unknown; B, Binalud; KD, Kopeh Dagh; EA, eastern Alborz; WA, western Alborz; MT, Meshkan 1217 transition zone; F, Fariman town; SB, Sistan belt; Za, Zagros; M, Mosha; T, Taleghan; MM, 1218 Mahneshan - Mianeh . Different tectonic regimes are characterized by different symbol colors. NF 1219 and NS data is printed in red, SS data in green, and TF and TS data in blue. Data with an unknown 1220 regime is printed in black. (B) Our inversion results $\left(\mathrm{N} 050 \pm 05^{\circ} \mathrm{E}\right.$ trending $\left.\sigma_{1}\right)$ showing the present1221 day state of stress in Dasht-e Bayaz area, source parameters were used from instrumentally recorded 1222 earthquakes that have been modeled using body waves (Walker et al., 2004), see the caption of Table 12232 for more details. We put into practice inversion of focal mechanisms by using moderate to large 1224 earthquakes $(7.1>\mathrm{M}>5.7)$ and employing the method proposed by Carey-Gailhardis and Mercier 1225 (1987). 

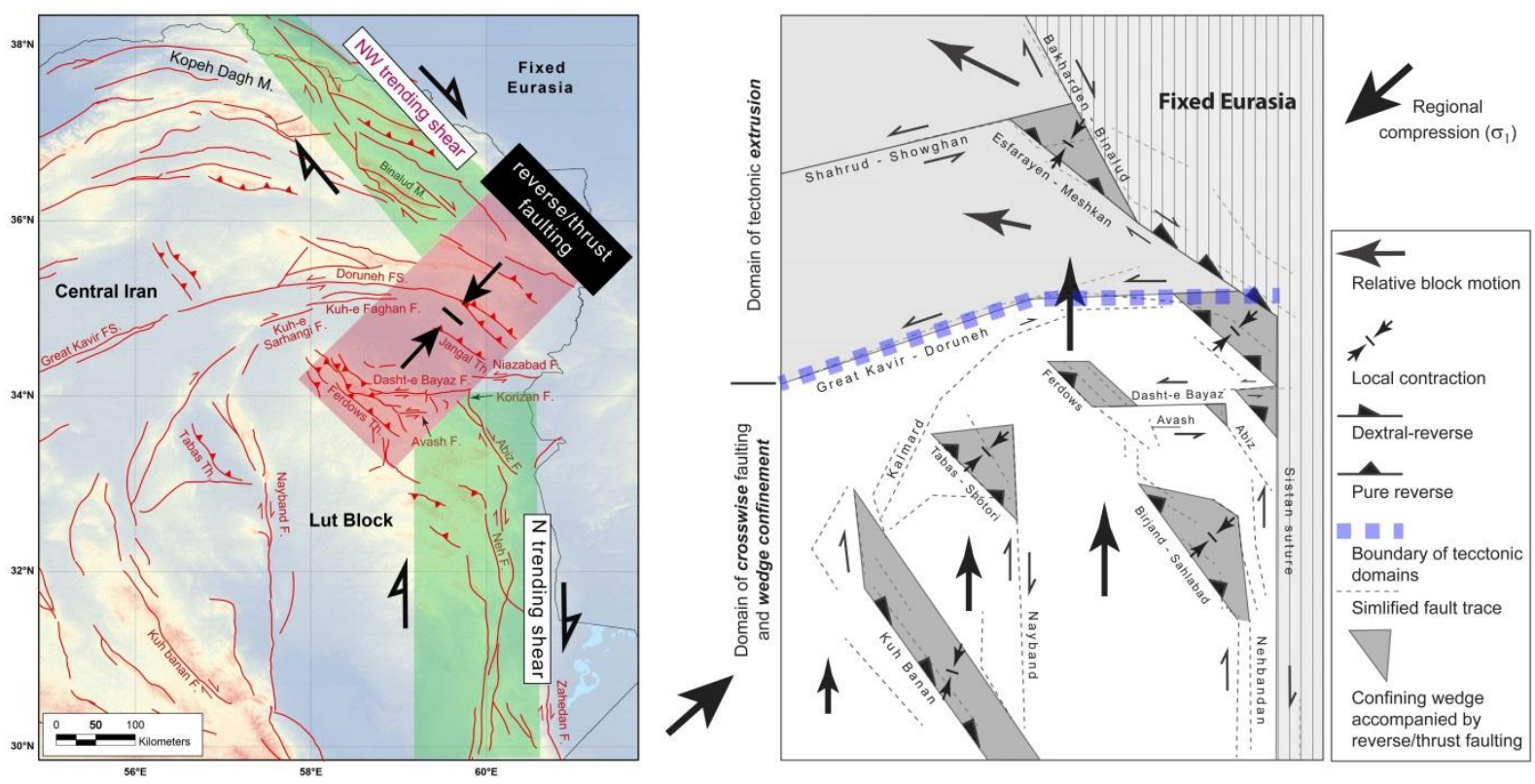

Figure 16. A brief explanation of our model about the northern Lut block and the southern

1228 Kopeh Dagh domain. (A) Up to latitude $34^{\circ} \mathrm{N}$ the majority of convergence is accommodated by right-

1229 lateral shear between Iranian plateau and fixed Eurasia. To the north of latitude $34^{\circ} \mathrm{N}$, an interruption

1230 in right-lateral shear takes place and in the absence of right-lateral shear, convergence is

1231 accommodated by reverse/thrust faulting. (B) Schematic model emphasizing the role of separated

1232 thrust zones, as confining wedges at the termination of N-S dextral fault, in accommodation of the

1233 Arabia-Eurasia convergence. See text for more information. 

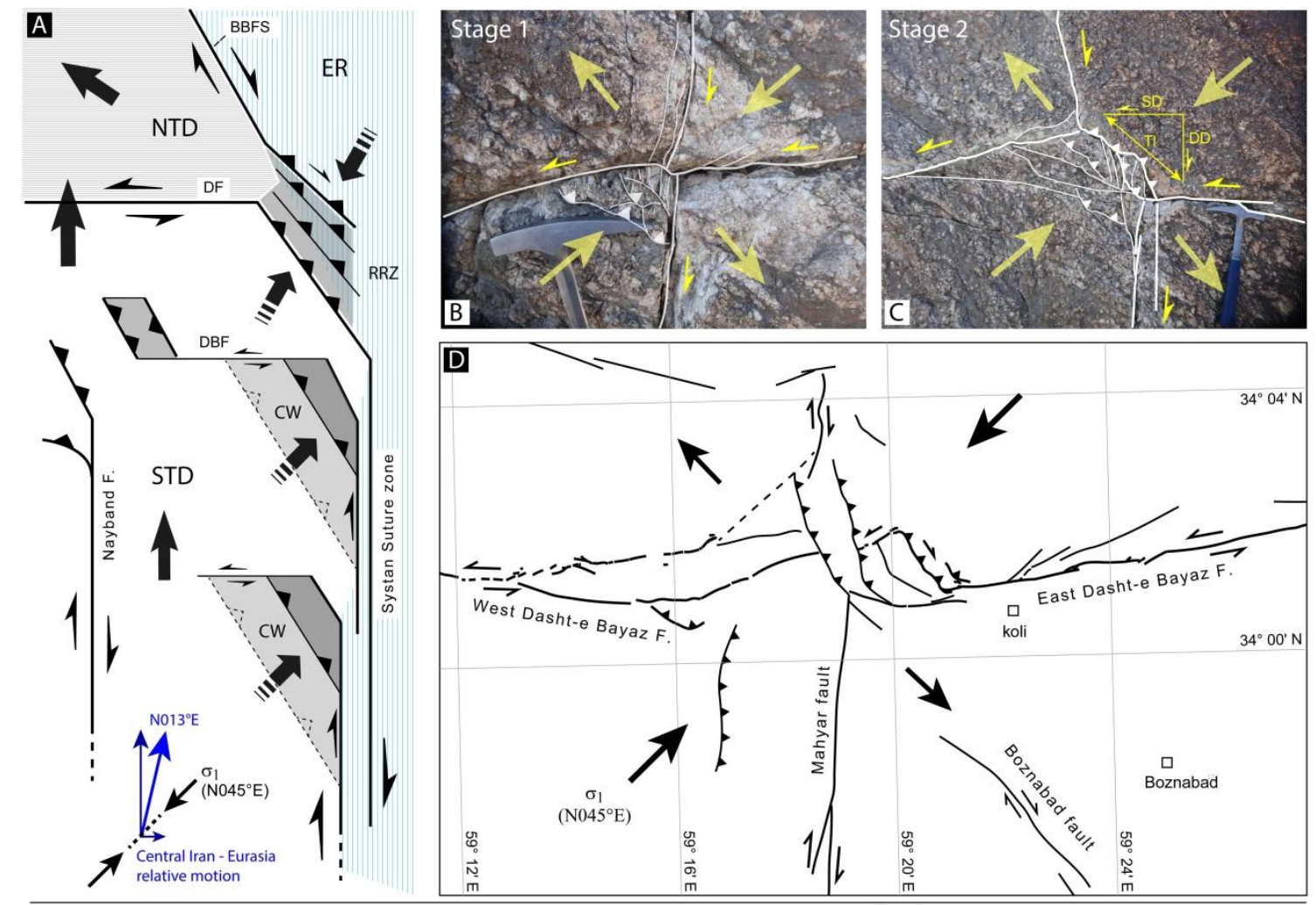

Relative block motion (Eurasia fixed)

III Shortening due to reverse faulting

Area confined in restraining zones

Figure 17. Details on the processes involved in the accommodation of Lut - Eurasia convergence in the NE and E Iranian regions. (A) The process of wedge confining at the edges of

1241 north-going blocks and the associated secondary sinistral faulting along E-W faults such as the Dasht-

1242 e Bayaz and Niazabad. The overall N013 ${ }^{\circ} \mathrm{E}$ direction of Lut - Eurasia motion (Walpersdorf et al.,

1243 2014) is mainly taken up by lithospheric N-S dextral shear translating the southern tectonic domain

1244 (STD) northwards. Shortening at the opposing edges of the main blocks (STD against ER) is accommodated through reverse faulting in a restraining relay zone (RRZ in "A"; Farbod, 2012; Aflaki et al., 2019), while internal deformations due to sub-block adjustments is taken up by crosswise

1247 dextral and sinistral faulting accompanied by contractional deformation at their terminations (CW,

1248 confining wedge); BBFS, Bakharden - Binalud fault system; DF, Doruneh fault; DBF, Dasht-e Bayaz

1249 fault. (B) And (C) Site-scale examples for the evolution of crosswise faulting; (B) illustrates the initial

1250 stage of crosswise faulting and (C) shows the structural configuration of crosswise dextral and sinistral faults after development of contractional quadrants. "TL" is the length of the main thrust fault zone developed perpendicular to the compression and is proportional to the amount of dextral (DD) and sinistral (SD) displacements of the main crosswise fault traces. (D) The intersection zone between the Dasht-e Bayaz and Mahyar faults; note to the analogy between this structural configuration and the typical crosswise faulting illustrated in (C). Such kind of kinematic interaction accommodates the overall convergence oblique to the faults without a need for rotations of faults and blocks around vertical axes. 
Table 1

The fault kinematic inversion results characterizing the Pliocene-Quaternary stress regimes in the Dasht-e Bayaz area.

\begin{tabular}{|c|c|c|c|c|c|c|c|c|c|c|c|c|c|c|c|c|c|c|c|c|c|c|c|c|c|}
\hline \multirow{3}{*}{ Site } & \multirow{3}{*}{$\begin{array}{l}\text { Long. } \\
\left({ }^{\circ} \mathrm{E}\right)\end{array}$} & \multirow{3}{*}{$\begin{array}{l}\text { Lat. } \\
\left({ }^{\circ} \mathrm{N}\right)\end{array}$} & \multicolumn{5}{|c|}{ Paleostress } & \multicolumn{9}{|c|}{ Modern Stress } & \multicolumn{7}{|c|}{ Intermediate Stress } & \multirow[t]{3}{*}{ Lithology } & \multirow[t]{3}{*}{ Age } \\
\hline & & & \multicolumn{3}{|c|}{ Stress axis(trend/plunge) } & \multirow[t]{2}{*}{$\mathrm{R}$} & \multirow[t]{2}{*}{$\mathrm{N}$} & \multirow[t]{2}{*}{ Q } & \multirow[t]{2}{*}{$\mathrm{Rm}$} & \multicolumn{3}{|c|}{ Stress axis(trend/plunge) } & \multirow[t]{2}{*}{$\mathrm{R}$} & \multirow[t]{2}{*}{$\mathrm{N}$} & \multirow[t]{2}{*}{ Q } & \multirow[t]{2}{*}{$\mathrm{Rm}$} & \multicolumn{3}{|c|}{ Stress axis(trend/plunge) } & \multirow[t]{2}{*}{$\mathrm{R}$} & \multirow[t]{2}{*}{$\mathrm{N}$} & \multirow[t]{2}{*}{ Q } & \multirow[t]{2}{*}{$\mathrm{Rm}$} & & \\
\hline & & & $\sigma 1$ & $\sigma 2$ & $\sigma 3$ & & & & & $\sigma 1$ & $\sigma 2$ & $\sigma 3$ & & & & & $\sigma 1$ & $\sigma 2$ & $\sigma 3$ & & & & & & \\
\hline 1 & 59.807 & 34.013 & $152 / 00$ & $62 / 00$ & $295 / 90$ & 0.595 & 4 & $\mathrm{CF}$ & $\mathrm{C}$ & $28 / 03$ & $293 / 61$ & $119 / 29$ & 0.51 & 10 & B & $\mathrm{s}$ & - & - & - & - & - & - & - & Andesite & Paleo-Eocene \\
\hline 2 & 59.101 & 34.041 & $120 / 01$ & $210 / 01$ & $345 / 89$ & 0.500 & 4 & $\mathrm{CF}$ & $\mathrm{C}$ & $53 / 05$ & $157 / 70$ & $321 / 19$ & 0.47 & 12 & A & $\mathrm{s}$ & - & - & - & - & - & - & - & Sandstone & Triassic \\
\hline 3 & 58.931 & 34.048 & - & - & - & - & - & - & - & $40 / 11$ & $176 / 75$ & $308 / 10$ & 0.55 & 8 & A & $\mathrm{S}$ & $357 / 9$ & $250 / 60$ & $92 / 28$ & 0.44 & 6 & $\mathrm{C}$ & $\mathrm{s}$ & Conglomerate & Quaternary \\
\hline 4 & 59.248 & 34.026 & $127 / 00$ & $303 / 90$ & $37 / 00$ & 0.327 & 4 & $\mathrm{CF}$ & $\mathrm{S}$ & $240 / 15$ & $43 / 75$ & $149 / 04$ & 0.43 & 12 & A & $\mathrm{S}$ & - & - & - & - & - & - & - & Andesite & Paleo-Eocene \\
\hline $5 \mathrm{~A}$ & 58.977 & 34.043 & - & - & - & - & - & - & - & $218 / 03$ & $116 / 76$ & $308 / 14$ & 0.66 & 12 & A & $\mathrm{s}$ & - & - & - & - & - & - & - & Conglomerate & Quaternary \\
\hline $5 \mathrm{~B}$ & 58.977 & 34.043 & - & - & - & - & - & - & - & $256 / 01$ & $354 / 83$ & $166 / 07$ & 0.714 & 8 & A & $\mathrm{s}$ & - & - & - & - & - & - & - & Conglomerate & Quaternary \\
\hline 6 & 58.738 & 34.028 & $119 / 05$ & $212 / 28$ & $19 / 62$ & 0.452 & 4 & $\mathrm{C}$ & $\mathrm{C}$ & $73 / 06$ & $343 / 01$ & $241 / 84$ & 0.23 & 14 & B & $\mathrm{C}$ & $20 / 15$ & $112 / 07$ & $227 / 74$ & 0.12 & 6 & A & $\mathrm{C}$ & Conglomerate & Pliocene \\
\hline 7 & 58.561 & 34.017 & $161 / 06$ & $252 / 12$ & $46 / 76$ & 0.696 & 5 & B & $\mathrm{C}$ & $230 / 02$ & $320 / 05$ & $124 / 85$ & 0.78 & 14 & A & $\mathrm{C}$ & - & - & - & - & - & - & - & Conglomerate & Pliocene \\
\hline 8 & 59.281 & 34.032 & - & - & - & - & - & - & - & $41 / 07$ & $279 / 76$ & $133 / 11$ & 0.96 & 10 & A & $\mathrm{s}$ & - & - & - & - & - & - & - & Tuff & Paleocene \\
\hline 9 & 59.168 & 34.027 & - & - & - & - & - & - & - & $40 / 07$ & $232 / 82$ & $130 / 2$ & 0.530 & 14 & A & $S$ & - & - & - & - & - & - & - & Dolomite & Triassic \\
\hline 10 & 59.274 & 34.028 & $120 / 00$ & $210 / 00$ & $354 / 90$ & 0.6 & 5 & $\mathrm{CF}$ & $\mathrm{C}$ & $217 / 00$ & $103 / 89$ & $307 / 01$ & 0.624 & 15 & A & $\mathrm{S}$ & - & - & - & - & - & - & - & Limestone & Paleocene \\
\hline
\end{tabular}

Note: Site numbers and their geographic coordination refer to Figure 9. The results of inversion of fault slip data are including trend and plunge of principal stress axes ( $\sigma 1$, $\sigma 2, \sigma 3$ (matching maximum, intermediate and minimum stress axes, respectively) and stress ratio " $R=(\sigma 2-\sigma 1) /(\sigma 3-\sigma 1)$ " shows the relative stress magnitude. N, number of fault slip data involved in stress calculations; $\mathrm{Rm}$ points out to stress regimes: C, compressional; S, strike-slip; Q indicates the quality of stress tensors: A, well-constrained; B, constrained; C, poorly-constrained solutions. CF quality represents data sets consist of less than four spatially well-distributed fault slip data, for this kind of data sets a "fixed" solutions (Bellier and Zoback, 1995) is used, in which the principal stress axes were fixed to lie in horizontal and vertical planes. In site 5, two deviatoric stress tensors (5A and 5B) were obtained. 
Table 2

Earthquake source parameters used in the focal mechanism inversion.

\begin{tabular}{llllllllll}
\hline Date & Time $(\mathrm{UTC})$ & $\mathrm{Y}$ & $\mathrm{X}$ & Depth $(\mathrm{km})$ & Magnitude $(\mathrm{Mw})$ & Strike & Dip & Rake & Reference \\
\hline 1968.08 .31 & $10: 47$ & 34.068 & 59.018 & 17 & $7.1 \mathrm{~m}$ & 254 & 84 & 5 & 5 \\
1968.08 .31 & $10: 47$ & 34.068 & 59.018 & 10 & 6.4 & 320 & 70 & 90 & 5 \\
1968.09 .01 & $07: 27$ & 34.099 & 58.155 & 9 & 6.3 & 115 & 54 & 85 & 3 \\
1968.09 .04 & $23: 24$ & 34.042 & 58.244 & 9 & 5.5 & 148 & 56 & 81 & 3 \\
1968.09 .11 & $19: 17$ & 34.031 & 59.472 & 6 & 5.6 & 78 & 90 & 16 & 1 \\
1976.11 .07 & $04: 00$ & 33.836 & 59.171 & 8 & $6.0 \mathrm{~m}$ & 84 & 79 & 12 & 1,4 \\
1976.11 .07 & $04: 00$ & 33.836 & 59.171 & 10 & & 67 & 52 & -7 & 1 \\
1979.01 .16 & $09: 50$ & 33.961 & 59.501 & 11 & $6.5 \mathrm{~m}$ & 293 & 34 & 46 & 1,4 \\
1979.01 .16 & $09: 50$ & 33.961 & 59.501 & 13 & & 257 & 88 & 5 & 1 \\
1979.11 .14 & $02: 21$ & 34.017 & 59.78 & 10 & $6.6 \mathrm{~m}$ & 160 & 89 & -177 & 1,4 \\
1979.11 .14 & $02: 21$ & 34.017 & 59.78 & 6 & & 85 & 85 & 1 & 1 \\
1979.11 .27 & $17: 10$ & 34.056 & 59.769 & 8 & $7.1 \mathrm{~m}$ & 261 & 82 & 8 & 5 \\
1979.12 .07 & $09: 24$ & 34.13 & 59.889 & 10 & 5.9 & 113 & 84 & 21 & 1 \\
1997.05 .10 & $07: 57$ & 33.88 & 59.815 & 13 & 7.2 & 156 & 89 & -160 & 2 \\
1997.06 .25 & $19: 38$ & 33.972 & 59.459 & 8 & 5.7 & 181 & 87 & 170
\end{tabular}

Note: In this research we used the source parameters of instrumentally recorded earthquakes in the Dasht-e Bayaz region that have been modeled by Walker et al. (2004) with body wave methods. References are the same as they used in their modeling, including: (1) Baker (1993), (2) Berberian et al. (1999), (3) Walker et al. (2003), (4) Jackson (2001) and (5) Walker et al. (2004). An (m) after of some of Mw means a multiple event. For more information see Table 1 of Walker et al. (2011). 
Table 1

The fault kinematic inversion results characterizing the Pliocene-Quaternary stress regimes in the Dasht-e Bayaz area.

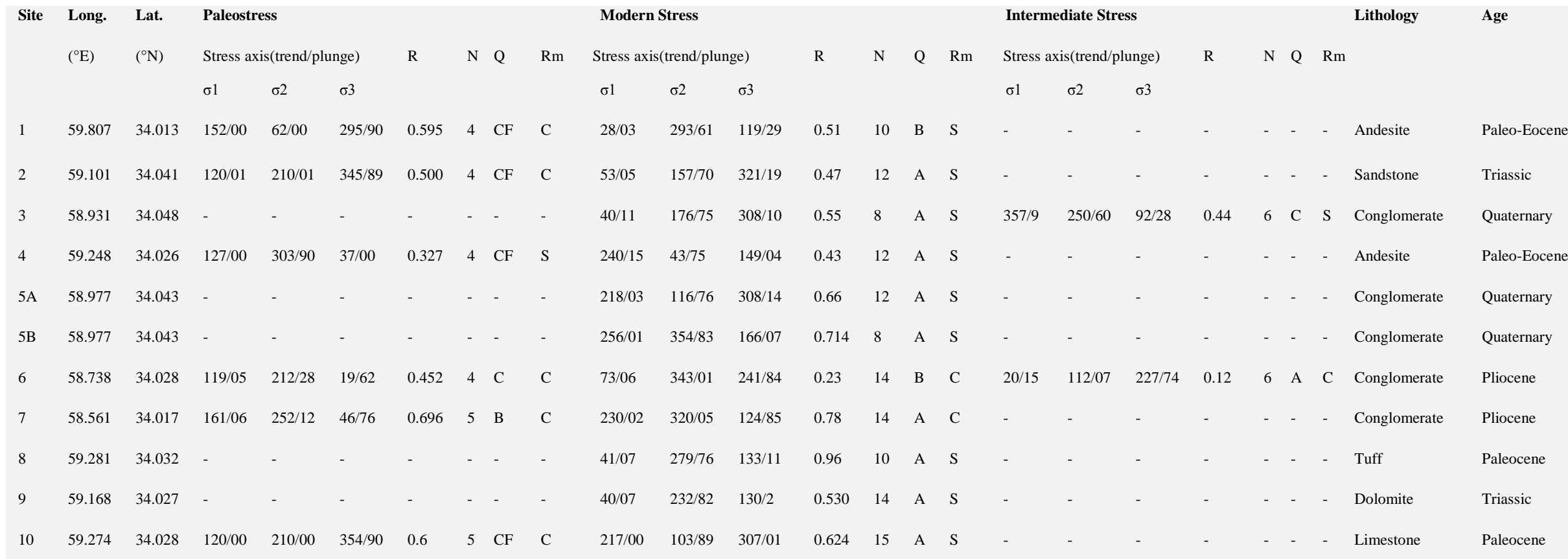

Note: Site numbers and their geographic coordination refer to Figure 9 . The results of inversion of fault slip data are including trend and plunge of principal stress axes ( $\sigma 1$, $\sigma 2, \sigma 3$ (matching maximum, intermediate and minimum stress axes, respectively) and stress ratio "R= $(\sigma 2-\sigma 1) /(\sigma 3-\sigma 1)$ " shows the relative stress magnitude. $\mathrm{N}$, number of fault slip data involved in stress calculations; Rm points out to stress regimes: C, compressional; S, strike-slip; Q indicates the quality of stress tensors: A, well-constrained; B, constrained; C, poorly-constrained solutions. CF quality represents data sets consist of less than four spatially well-distributed fault slip data, for this kind of data sets a "fixed" solutions (Bellier and Zoback, 1995) is used, in which the principal stress axes were fixed to lie in horizontal and vertical planes. In site 5, two deviatoric stress tensors (5A and 5B) were obtained. 
Table 2

Earthquake source parameters used in the focal mechanism inversion.

\begin{tabular}{llllllllll}
\hline Date & Time $(\mathrm{UTC})$ & $\mathrm{Y}$ & $\mathrm{X}$ & Depth $(\mathrm{km})$ & Magnitude $(\mathrm{Mw})$ & Strike & Dip & Rake & Reference \\
\hline 1968.08 .31 & $10: 47$ & 34.068 & 59.018 & 17 & $7.1 \mathrm{~m}$ & 254 & 84 & 5 & 5 \\
1968.08 .31 & $10: 47$ & 34.068 & 59.018 & 10 & 6.4 & 320 & 70 & 90 & 5 \\
1968.09 .01 & $07: 27$ & 34.099 & 58.155 & 9 & 6.3 & 115 & 54 & 85 & 3 \\
1968.09 .04 & $23: 24$ & 34.042 & 58.244 & 9 & 5.5 & 148 & 56 & 81 & 3 \\
1968.09 .11 & $19: 17$ & 34.031 & 59.472 & 6 & 5.6 & 78 & 90 & 16 & 1 \\
1976.11 .07 & $04: 00$ & 33.836 & 59.171 & 8 & $6.0 \mathrm{~m}$ & 84 & 79 & 12 & 1,4 \\
1976.11 .07 & $04: 00$ & 33.836 & 59.171 & 10 & & 67 & 52 & -7 & 1 \\
1979.01 .16 & $09: 50$ & 33.961 & 59.501 & 11 & $6.5 \mathrm{~m}$ & 293 & 34 & 46 & 1,4 \\
1979.01 .16 & $09: 50$ & 33.961 & 59.501 & 13 & & 257 & 88 & 5 & 1 \\
1979.11 .14 & $02: 21$ & 34.017 & 59.78 & 10 & $6.6 \mathrm{~m}$ & 160 & 89 & -177 & 1,4 \\
1979.11 .14 & $02: 21$ & 34.017 & 59.78 & 6 & & 85 & 85 & 1 & 1 \\
1979.11 .27 & $17: 10$ & 34.056 & 59.769 & 8 & $7.1 \mathrm{~m}$ & 261 & 82 & 8 & 5 \\
1979.12 .07 & $09: 24$ & 34.13 & 59.889 & 10 & 5.9 & 113 & 84 & 21 & 1 \\
1997.05 .10 & $07: 57$ & 33.88 & 59.815 & 13 & 7.2 & 156 & 89 & -160 & 2 \\
1997.06 .25 & $19: 38$ & 33.972 & 59.459 & 8 & 5.7 & 181 & 87 & 170 & 2
\end{tabular}

Note: In this research we used the source parameters of instrumentally recorded earthquakes in the Dasht-e Bayaz region that have been modeled by Walker et al. (2004) with body wave methods. References are the same as they used in their modeling, including: (1) Baker (1993), (2) Berberian et al. (1999), (3) Walker et al. (2003), (4)

Jackson (2001) and (5) Walker et al. (2004). An (m) after of some of Mw means a multiple event. For more information see Table 1 of Walker et al. (2011). 